\title{
Chitosan for Direct Bioflocculation Processes
}

\author{
Eric Lichtfouse, Nadia Morin-Crini, Marc Fourmentin, Hassiba Zemmouri, \\ Inara Oliveira Carmo do Nascimento, Luciano Matos Queiroz, \\ Mohd Yuhyi Mohd Tadza, Lorenzo A. Picos-Corrales, Haiyan Pei, \\ Lee D. Wilson, and Grégorio Crini
}

\begin{abstract}
Coagulation-flocculation is a major process allowing to remove suspended particles from municipal and industrial wastewater. This process commonly involves metal salts as coagulants and synthetic organic polymers as flocculants. Although those chemicals are cheap, efficient, available and easy to use, they have drawbacks such water pollution by metals, and production of large amounts of toxic sludges. Therefore, safer biocoagulants and bioflocculants of biological origin are currently developed. For instance, the direct flocculation process involves water-soluble, ionic organic polymers, and thus do not need the addition of metal
\end{abstract}

\footnotetext{
E. Lichtfouse $(\bowtie)$

Aix-Marseille Université, CNRS, IRD, INRA, Coll France, CEREGE, Aix-en-Provence, France e-mail: eric.lichtfouse@inra.fr

N. Morin-Crini $(\bowtie)$

Laboratoire Chrono-environnement, UMR 6249, UFR Sciences et Techniques, Université

Bourgogne Franche-Comté, Besançon, France

e-mail: nadia.crini@univ-fcomte.fr

M. Fourmentin

Université du Littoral Côte d'Opale, Laboratoire de Physico-Chimie de l'Atmosphère (LPCA, EA 4493), ULCO, Dunkerque, France

e-mail: marc.fourmentin@univ-littoral.fr

H. Zemmouri

Laboratoire des Sciences et du Génie des Procédés Industriels, Faculté de Génie Mécanique et Génie des Procédés, Université des Sciences et de la Technologie Houari Boumediene, Alger, Algeria

I. O. C. do Nascimento · L. M. Queiroz

Department of Environmental Engineering, Federal University of Bahia, Polytechnic School,

Salvador, Bahia, Brazil

e-mail: 1mqueiroz@ufba.br

M. Y. M. Tadza

Faculty of Civil Engineering \& Earth Resources, Universiti Malaysia Pahang, Gambang,

Kuantan, Malaysia

e-mail: dryuhyi@ump.edu.my
}

In G. Crini, E. Lichtfouse (eds.), Sustainable Agriculture Reviews 36,

https://doi.org/10.1007/978-3-030-16581-9_9 
coagulants. In particular, chitosan and byproducts have been recently designed as bioflocculants to remove particulate matter and dissolved pollutants. Chitosan is a partially deacetylated polysaccharide obtained from chitin, a biopolymer extracted from shellfish sources. Chitosan exhibits various physicochemical and functional properties of interest for many environmental applications.

Key achievements of chitosan applications include the removal of more than $90 \%$ of solids and $95 \%$ of residual oil from palm oil mill effluents. Chitosan highly reduces the turbidity of agricultural wastewater and seawater. Comparison of raw chitosan with modified chitosan, such as 3-chloro-2-hydroxypropyl trimethylammonium chloride grafted onto carboxymethyl-chitosan, to treat a solution of high turbidity $(400 \mathrm{mg} / \mathrm{L}$ kaolinite) and phosphate $(25 \mathrm{mg} / \mathrm{L})$, shows that the modified chitosan decreases the turbidity by $99 \%$ and the phosphate content by $97 \%$ at all $\mathrm{pH}$, whereas those abatements are below $80 \%$ for the raw chitosan. Chitosan also removes toxic Microcystis aeruginosa cyanobacterial cells by $99 \%$ and microcystins by $50 \%$. This chapter discusses advantages and drawbacks of using chitosan for direct flocculation for water and wastewater treatment, sludge dewatering, and post-treatment of sanitary landfill leachates.

Keywords Chitosan · Bioflocculant $\cdot$ Direct bioflocculation $\cdot$ Wastewater treatment $\cdot$ Sludge dewatering

\subsection{Introduction}

Coagulation and flocculation are two frequently applied processes in the water treatment industry for solids removal, water clarification, drinking water treatment, decontamination of wastewaters, solids dewatering, sludge thickening, and lime softening (Bratby 2006; Oladoja 2015; Morin-Crini and Crini 2017; Wei et al. 2018). Chemical reagents are often used at the first stage of solids-liquids separation in a wastewater treatment plant to facilitate the removal of suspended and colloidal particles.

During wastewater treatment, coagulation and flocculation occur in two main successive steps (Fig. 9.1), namely a destabilization step and an aggregation step

L. A. Picos-Corrales

Facultad de Ciencias Químico Biológicas, Universidad Autónoma de Sinaloa, Blvd. de las Américas y Josefa Ortiz de Domínguez, Ciudad Universitaria, Culiacán, Sinaloa, Mexico e-mail: lorenzo.picos.c@uas.edu.mx

H. Pei

School of Environmental Science and Technology, Shandong University, Jinan, China

L. D. Wilson

Department of Chemistry, University of Saskatchewan, Saskatoon, Canada

e-mail: lee.wilson@usask.ca

G. Crini $(\bowtie)$

Chrono-Environnement, UMR 6249, Université Bourgogne Franche-Comté, Besançon, France

e-mail: gregorio.crini@univ-fcomte.fr 


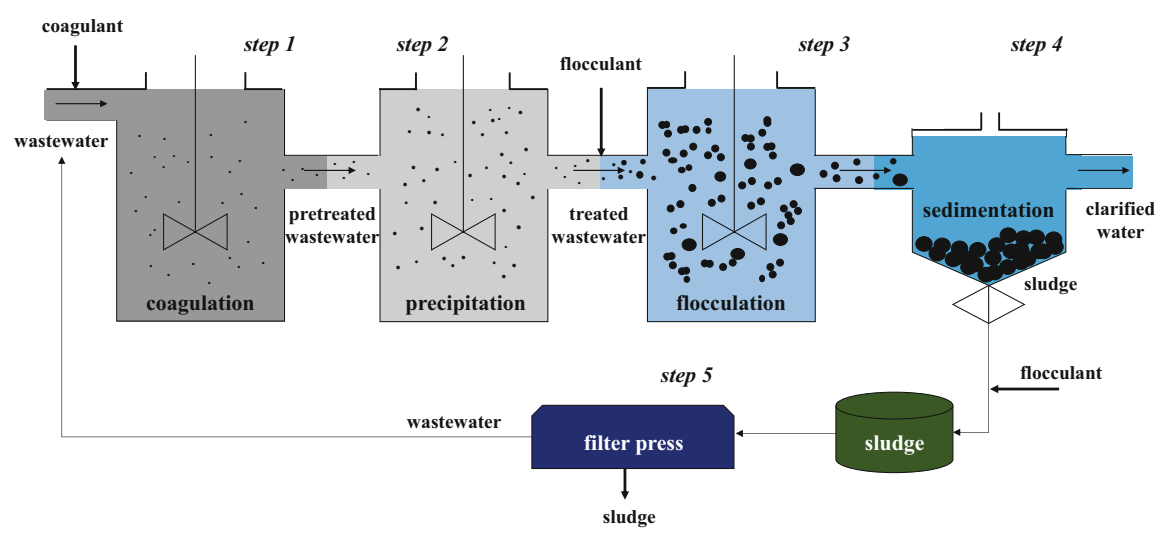

Fig. 9.1 The coagulation-flocculation process in a physicochemical wastewater treatment plant. An inorganic coagulant such as a metal salt is added at step 1 to alter the physical state of dissolved and suspended solids, in order to obtain complex precipitates of metal hydroxides at the desired $\mathrm{pH}$ for precipitation at step 2, and to facilitate further sedimentation at step 4. Precipitation at step 2 is is followed by the addition of flocculants or coagulant aids at step 3 to enhance the treatment efficiency and sedimentation rate by aggregation of microflocs into visible, dense, and rapid settling flocs. The filter press at step 5 allows to filtrate the sludge under pressure in order to separate the liquid phase (filtrate) from the solid phase: the cake

(Bratby 1980; Cox et al. 2007). These processes combine insoluble particles such as solids and colloids, dissolved organic matter, organics, inorganics and microorganisms into large aggregates, thereby facilitating their removal in subsequent stages of sedimentation and filtration. Additional operations include the removal of target substances, i.e. phosphates and oils, color and odor, and recovery of valuable products such as proteins and microalgae.

Coagulation-flocculation is also an important phenomenon during sludge dewatering to extract water from the solids. Actually, the disposal or recycling of wastewater sludge, in particular the minimization of sludge volume, is a major challenge for the water treatment industry. Sludge dewatering separates sludge into liquid and solid components, with the aims of waste minimization and cost efficiency of disposal and recycling.

Coagulation using a chemical coagulant is a chemical-driven process whereby a given system, solution or suspension, is transformed from a stable into an unstable state. The destabilization step involves charge neutralization. The coagulation aim is indeed to counter the factors that promote the system stability. This step usually involves the addition of chemical reagents, e.g. a coagulant, which destabilizes the suspended solids and pollutants and, in turn, allows their agglomeration, leading to the formation of micro-flocs (Bratby 1980, 2006). Then, bonding these micro-flocs together by the addition of a flocculant, forms larger, denser aggregates that settle rapidly and are easier to separate. Flocculation is the aggregation step. Then, a simple separation step, e.g. settling, flotation or filtration, separates the flocs and produces a clarified water. Overall, flocculation used in conjunction with coagulation is the process whereby the manifestation of destabilization is realized in 
practicable terms (Bratby 1980, 2006). A flocculant aid is a chemical substance added to a coagulated system to bridge the particles together, to form bigger aggregates or flocs in size, to accelerate the rate of flocculation and to strengthen flocs formed during flocculation. This process strongly influences the physical characteristics of flocs, e.g. their size, strength and density.

Coagulation and flocculation are sequential processes distinguished primarily by the types of chemicals used and the size of the particles formed. There are two major classes of commercial chemicals used (Fig. 9.2): (1) inorganic and organic coagulants including mineral additives, hydrolyzing metal salts, pre-hydrolyzed metals and polyelectrolytes; and (2) organic flocculants including cationic and anionic polyelectrolytes, non-ionic polymers, amphoteric and hydrophobically modified polymers, and naturally occurring flocculants (Bratby 2006; Bolto and Gregory 2007).

Coagulation is mainly induced by metal salts. Common metal coagulants fall into two general categories: aluminium and iron salts. The most common coagulants are aluminium sulfate, generally known as alum, polyaluminium chloride (PAC), ferric chloride, ferric sulfate, and polyferric sulfate (PFS). The addition of these cations contribute to colloidal destabilization, as they specifically interact with, and neutralize the negatively charged colloids (Stechemesser and Dobiáš 2005; Bratby 2006). Their popularity arises not only from their effectiveness but also from their ready availability and low-cost.

Flocculants are classified into polymeric inorganic-based products and polymeric organic-based materials (Fig. 9.2). Polyelectrolyte flocculants are mainly linear or branched organic macromolecules. Flocculants can be of synthetic or natural origin. Synthetic macromolecules are based on monomers such as acrylamide, acrylic acid, or dimethyldiallylammonium chloride. Naturally occurring products include starches, celluloses, alginates, gums and other plant derivatives (Levine 1981).

The most frequently used flocculants in industrial applications are polyacrylamide-based products such as nonionic polyacrylamides, anionic acrylamide-acrylate copolymers, partially hydrolyzed polyacrylamides, cationic dimethyldiallylammonium chlorides and copolymers of the dimethyldiallylammonium ion with acrylamide. The main advantage is their ability to produce large, dense, compact flocs that are stronger and have good settling characteristics compared to those obtained by coagulation. Polymeric organic flocculants are also easy to handle and immediately soluble in aqueous systems. They can reduce the sludge volume.

However, the use of synthetic coagulants and flocculants poses serious environmental and health problems and debates. For instance, the problems often cited are: production of large volumes of toxic sludge, low biodegradability, water pollution by toxic metals, e.g. aluminum salts are connected to Alzheimer's disease, and dispersion of acrylamide oligomers, which is also a health hazard because the acrylamide monomer is carcinogenic and neurotoxic to humans (Salehizadeh et al. 2018). For these reasons, alternative natural materials, named biocoagulants and bioflocculants, have been developped for wastewater treatment. Among them, chitosan, a partially deacetylated polysaccharide obtained from chitin, deserves particular attention. 


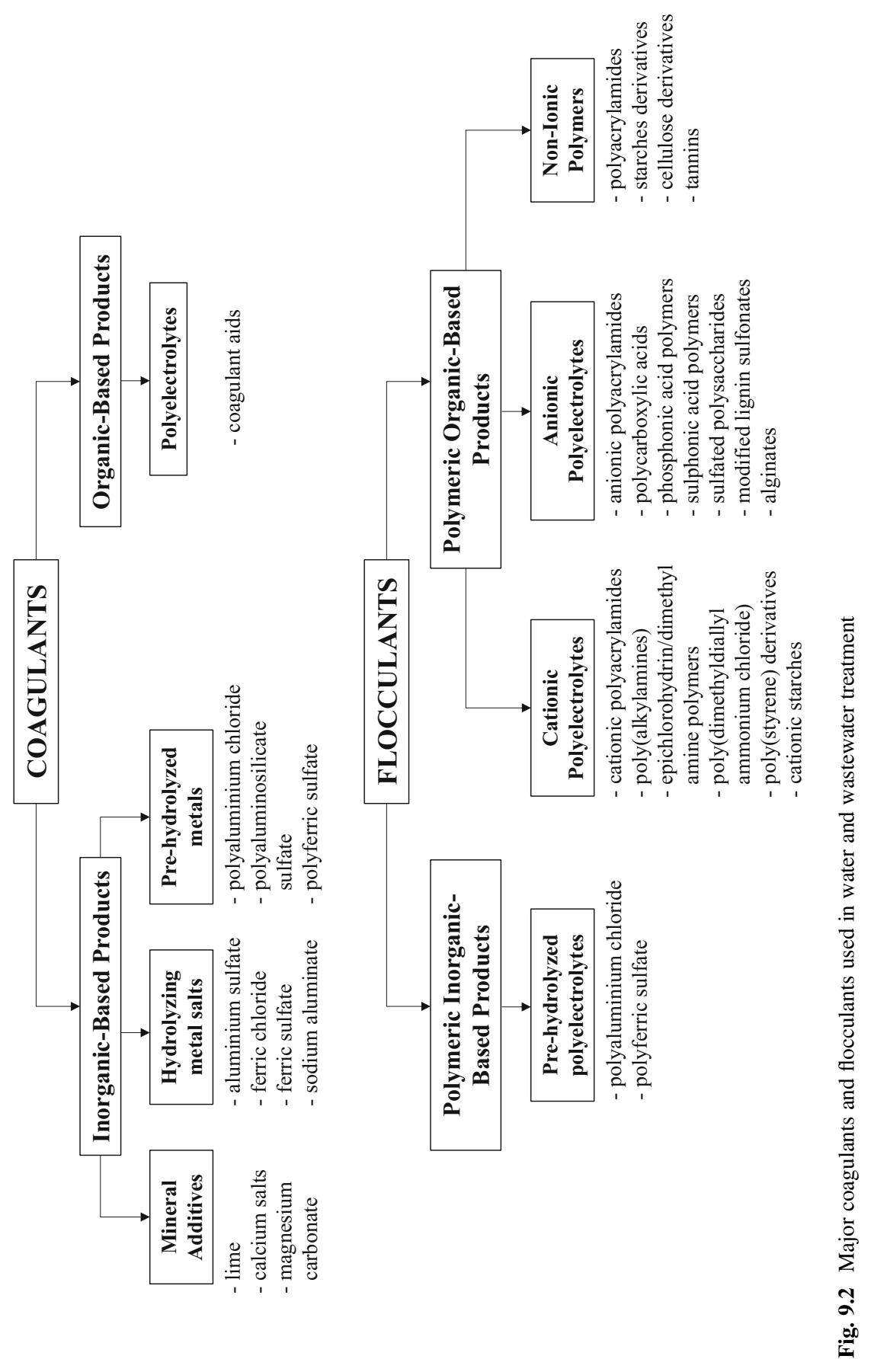


Chitin is a linear long-chain homo-polymer composed of $\mathrm{N}$-acetyl-glucosamine, characterized by its average degree of acetylation or degree of deacetylation and molecular weight. Chitin is commercially extracted from marine crustaceans, and is considered as a low-cost by-product of the seafood processing industry. Chitosan is a partially deacetylated polysaccharide obtained from chitin and is also characterized by its degree of deacetylation and molecular weight. Chitosan is an aminopolysaccharide which is non-toxic, biocompatible, biodegradable and classified as a green product. Chitosan exhibits a variety of physicochemical and functional properties resulting in numerous practical applications in medicine, pharmacy, cosmetology, food and nutrition, agriculture, agrochemistry, beverage industry, biotechnology, textile and paper industries, packaging, catalysis, and wastewater treatment (Onsoyen and Skaugrud 1990; Peters 1995; Goosen 1997; Kurita 1998, 2006; No and Meyers 2000; Ravi Kumar 2000; Dutta et al. 2004; Rinaudo 2006; Crini and Badot 2008; Crini et al. 2009a, b; Sudha 2011; Ujang et al. 2011; Vakili et al. 2014; Crini 2015; Vandenbossche et al. 2015; Yong et al. 2015; Bhalkaran and Wilson 2016; Agbovi et al. 2017; Arfin 2017; Bonecco et al. 2017; Dima et al. 2017; Wang and Zhuang 2017; de Andrade et al. 2018). Most applications rely on the cationic nature of chitosan in acidic media, e.g. allowing its dissolution in water as a polyelectrolyte, which is unique among abundant polysaccharides and natural polymers. Table 9.1 describes the practical applications of chitosan for environmental purposes, including in water and wastewater treatment.

The water-insoluble form of chitosan can be used as biosorbent for the removal of pollutants such as metals and metalloids, dyes, fluorides, pesticides, and endocrine

Table 9.1 Practical applications of chitosan for environmental purposes

\begin{tabular}{l}
\hline Coagulation of suspended solids, mineral and organic suspensions \\
\hline Reduction of turbidity \\
\hline Flocculant to clarify water, drinking water, pools and spas \\
\hline Flocculation of bacterial suspensions \\
\hline Chelation and elimination of metals \\
\hline Recovery of precious metals \\
\hline Dye removal, elimination of color \\
\hline Removal of pollutants: pesticides, phenols, fluorides, rare earth elements \\
\hline Recovery of valuable products such as proteins \\
\hline Ricroalgae harvesting \\
\hline Antifouling agent \\
\hline Polymer-assisted ultrafiltration \\
\hline Sludge treatment, sludge dewatering
\end{tabular}

References: Lee et al. (2014), Liu and Bai (2014), Vakili et al. (2014), Crini (2015), Vandenbossche et al. (2015), Yong et al. (2015), Azarova et al. (2016), Barbusinski et al. (2016), Yang et al. (2016), Crini et al. (2017), Kanmani et al. (2017), Kyzas et al. (2017), Sudha et al. (2017), Desbrières and Guibal (2018), El Halah et al. (2018), Nechita (2017), Pakdel and Peighambardoust (2018), Van Tran et al. (2018) 
disruptors. Biosorption is a process of separation based on the selective complexation of the pollutant molecules by the solid biosorbent. Effective sorption is controlled by specific interactions between the surface of the amino-polysaccharide and the adsorbed pollutants. The main interaction force is chemisorption, i.e. electrostatic attraction, ion-exchange or chelation. Further information can be found in the reviews by Crini (2015), Yong et al. (2015), Bhalkaran and Wilson (2016), Kanmani et al. (2017), Kyzas et al. (2017), Nechita (2017), Wang and Zhuang (2017), Desbrières and Guibal (2018), Pakdel and Peighambardoust (2018), and Van Tran et al. (2018).

The water-soluble form of chitosan can be used as a complexing agent in membrane filtration processes such as polymer-assisted ultrafiltration (Ang et al. 2016; Crini et al. 2017; Mohamed et al. 2018). This process involves a step of pollutant complexation by chitosan, then a step of filtration by an ultrafiltration membrane. Here, the macroligand-pollutant complex is held back, allowing purified water to go through the membrane. Crini et al. (2017) recently reviewed the advantages gained from the use of cationic chitosan in the process of complexation-ultrafiltration.

The cationic biopolymer chitosan has also drawn particular attention as a flocculating agent for application in water industries due to its biological origin, non-toxicity, eco-friendly character, low cost, and outstanding performances. In this chapter, after a brief description of the main advantages and possible drawbacks of using chitosan as bioflocculant, we highlight selected works on the use of chitosan products for target applications.

\subsection{Application of Chitosan as Bioflocculant}

\subsubsection{Coagulation and Flocculation in Wastewater Treatment}

Coagulation/flocculation is a common method for the decontamination of industrial and urban wastewaters and for water purification. The advantages are:

- technological simplicity, e.g. simple equipment, integrated physicochemical process, well established procedure, easy control and maintenance,

- economically advantageous, e.g. inexpensive initial capital cost, relatively low-cost in maintenance,

- rapid and efficient,

- adaptable to many treatments formats such as primary clarification, pretreatment, and/or final treatment and to high pollutant loads, including sludge treatment,

- very efficient for suspended solids, colloidal particles, and turbidity, efficient for biochemical oxygen demand and chemical oxygen demand removal,

- significant reduction of the dissolved organic content, total organic carbon, and pollutants such as metals, dyes, pigments, and fluorides, and also efficient for color and odor removal. 
Coagulation and flocculation occur in successive steps (Fig. 9.1). For wastewater treatment, the coagulation-flocculation process can be used at different stages. For instance, coagulation-flocculation as pretreatment consists of eliminating the floating, solid particles and all suspended substances from the effluents. As secondary treatment, coagulation/flocculation may be necessary to remove remaining pollutants produced during the physicochemical or biological treatments.

For the treatment of pulp and paper industry wastewaters, chemicals addition is typically done at one or more locations within the wastewater treatment plant, as shown in Fig. 9.3 (Renault et al. 2009a, b, c). For instance, the dosage points are as follows:

1. pretreatment: to remove much of the solids and fibers before the chemical and biological steps;

2. physicochemical primary treatment: coagulation, precipitation and/or oxidation;

3. flocculation and sedimentation using a primary clarifier;

4. biological treatment to treat both biochemical oxygen demand and chemical oxygen demand;

5. flocculation of biomass using a secondary clarifier; and

6. tertiary treatment.

Over the range of wastewater $\mathrm{pH}$, of about $7-8$, particles nearly always carry a negative surface charge and, as a consequence, are often colloidally stable and resistant to aggregation. A metal salt as coagulant is thus needed to destabilize the particles. Destabilization can be brought about by:

- either increasing the ionic strength, giving some reduction in the zeta potential and a decreased thickness of the diffuse part of the electrical double layer,

- or specifically adsorbing counterions to neutralize the particle charge.

Renault et al. (2009a, c) showed that the coagulation process is not always perfect as it may result in small flocs when coagulation takes place at low temperatures, or produce fragile flocs that break up when subjected to physical forces. To overcome these problems and also to improve the process in order to obtain good quality effluent and rapid sedimentation of the flocs formed, the industry uses a polymeric additive that permits association and agglomeration of the flocs formed by the coagulant. This flocculant can act either by polymer bridging or by charge neutralization, enhancing the formation of larger floc, and improving the rate of sedimentation.

Such processes can be done by chitosan because chitosan has specific macromolecular structures with a variety of functional groups, i.e. amino and hydroxyl groups, which can interact with pollutants. From the end of the 2000s, Crini's group proposed direct bioflocculation using low cost chitosan as a novel approach to treat wastewater from pulp and paper plant (Crini et al. 2009a, b; Renault et al. 2009a, b, c, d). Their works demonstrated that chitosan was able to combine the two functions of coagulation and flocculation in industrial wastewater treatment. Crini thus spoke of 'two-in-one' materials (Crini and Badot 2007; Crini et al. 2009a, b). 


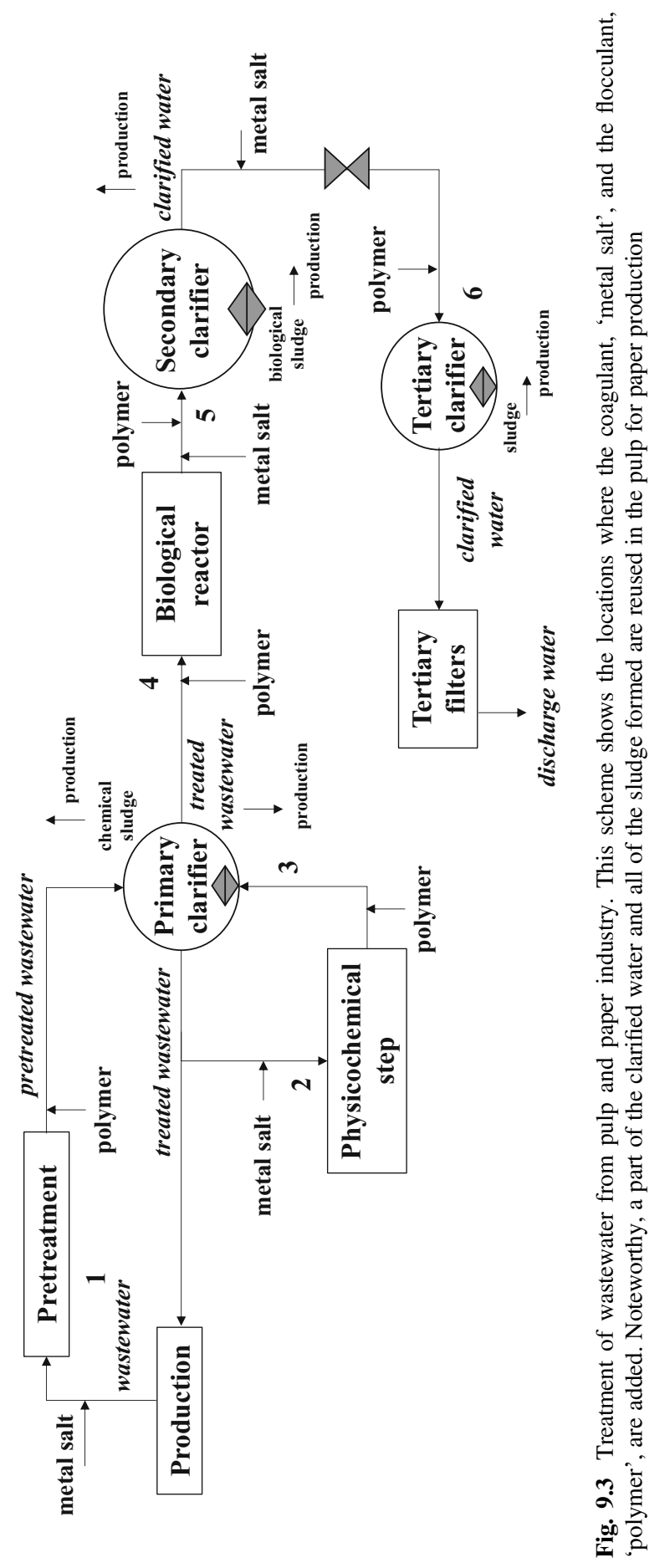




\subsubsection{Coagulation-Flocculation Versus Direct Flocculation}

Polymeric flocculants such as cationic polymers can be used in direct flocculation processes because they possess dual functions of coagulation and flocculation, i.e. neutralizing the negative charges and bridging the aggregated destabilized particles. Indeed, the direct flocculation using ionic polymers - without addition of coagulants - allows to completely replace inorganic coagulants by water-soluble organic polymers during chemical pretreatments, main treatments or posttreatments. The selection between conventional coagulation-flocculation and direct flocculation is highly depending on the type of wastewater. In general, the applications of direct flocculation using only polymeric flocculants are mainly limited to organic-based wastewater having high concentration of suspended and colloidal solids such as food, paper and pulp, and textile effluents.

\subsubsection{Direct Bioflocculation Using Chitosan}

In last decade there has been a rapid increase of the use of chitosan as bioflocculant and the development of new chitosan-based materials for direct bioflocculation process, e.g. grafted chitosans, composites and hybrid materials. Table 9.2 refers to reviews on the synthesis, characterization and properties of chitosan-based flocculants and their applications for bioflocculation. Table 9.3 presents selected examples of potential applications of chitosan in water and wastewater treatment, sludge dewatering, harvesting of microalgae and dissolved air flotation. All reports demonstrated that direct bioflocculation is an effective and competitive approach, and that chitosan is a promising bioflocculant for environmental and purification purposes (Chong 2012; Lee et al. 2014; Yang et al. 2016).

\subsubsection{Advantages of Using Chitosan as Bioflocculant}

Table 9.4 describes the main characteristics and properties of chitosan in relation to its use in flocculation application. They can be summarized as follows:

- Chitosan may be produced at relatively low cost. In many countries, fishery wastes are used as excellent sources to produce chitin and chitosan. For applications in wastewater treatment, chitosans are usually offered as flakes or powders with prices that range from 10 to $50 \mathrm{US} \$ / \mathrm{kg}$, depending mainly on the degree of deacetylation $(70 \%<$ value $<90 \%)$, molecular weight and purity (technical grade) parameters.

- Chitosan is a non-toxic, biocompatible and biodegradable resource, and a possible alternative to synthetic polymers as an ecofriendly product. It has also the advantage of being non corrosive and safe to handle, i.e. non-hazardous product, not irritating. 
Table 9.2 Reviews on chitosan-based bioflocculants for bioflocculation-oriented processes

\begin{tabular}{|c|c|c|}
\hline Pollution/Pollutant(s) & Topics & Reference \\
\hline SS, COD, metals, dyes & $\begin{array}{l}\text { Products, mechanism, performance, } \\
\text { wastewater treatment }\end{array}$ & $\begin{array}{l}\text { Crini et al. } \\
(2009 a)\end{array}$ \\
\hline SS, turbidity, COD, TOC, color & $\begin{array}{l}\text { Structure-activity relationship, chitosan } \\
\text { characteristics, process variables, mech- } \\
\text { anism, performance, wastewater } \\
\text { treatment }\end{array}$ & $\begin{array}{l}\text { Renault } \\
\text { et al. } \\
(2009 d)\end{array}$ \\
\hline Dyes, color & $\begin{array}{l}\text { Products, process variables, mechanism, } \\
\text { interactions, performance }\end{array}$ & $\begin{array}{l}\text { Verma et al. } \\
(2012)\end{array}$ \\
\hline $\begin{array}{l}\text { Turbidity, COD, color, phosphate, } \\
\text { nitrogen }\end{array}$ & $\begin{array}{l}\text { Chemical modification, hybrid materials, } \\
\text { preparation, characterization, operating } \\
\text { parameters }\end{array}$ & $\begin{array}{l}\text { Lee et al. } \\
(2012)\end{array}$ \\
\hline SS, turbidity, DOC & Products, mechanism, performance & \begin{tabular}{|l|} 
Oladoja \\
$(2015)$
\end{tabular} \\
\hline Arsenic, metals, turbidity & $\begin{array}{l}\text { Products, chemical modification, } \\
\text { chitosan characteristics, self-assembly } \\
\text { processes, process variables, mechanism, } \\
\text { performance, wastewater treatment }\end{array}$ & $\begin{array}{l}\text { Bhalkaran } \\
\text { and Wilson } \\
(2016)\end{array}$ \\
\hline SS, dissolved matter & $\begin{array}{l}\text { Products, chemical modification, } \\
\text { structure-activity relationship, chitosan } \\
\text { characteristics, process variables, mech- } \\
\text { anism, performance, water treatment, } \\
\text { wastewater treatment, toxicity, cost } \\
\text { performance }\end{array}$ & $\begin{array}{l}\text { Yang et al. } \\
\text { (2016) }\end{array}$ \\
\hline SS, dissolved matters, TOC & $\begin{array}{l}\text { Products, performance, papermaking } \\
\text { industry }\end{array}$ & $\begin{array}{l}\text { Song et al. } \\
(2018)\end{array}$ \\
\hline Metals & $\begin{array}{l}\text { Products, composites, wastewater treat- } \\
\text { ment, performances }\end{array}$ & $\begin{array}{l}\text { Kanmani } \\
\text { et al. (2017) }\end{array}$ \\
\hline $\begin{array}{l}\text { SS, turbidity, COD, dyes, color, } \\
\text { metals, harvesting and cell recovery, } \\
\text { sludge dewatering }\end{array}$ & $\begin{array}{l}\text { Chemical modification, preparation, bio- } \\
\text { synthesis, operating parameters, mecha- } \\
\text { nisms, performances }\end{array}$ & $\begin{array}{l}\text { Salehizadeh } \\
\text { et al. (2018) }\end{array}$ \\
\hline Harvesting of microalgae & $\begin{array}{l}\text { Flotation, operating parameters, } \\
\text { performance }\end{array}$ & $\begin{array}{l}\text { Laamanen } \\
\text { et al. (2016) }\end{array}$ \\
\hline Microalgae & $\begin{array}{l}\text { Products, flocculation strategies, process } \\
\text { variables, mechanism, interactions, } \\
\text { performance }\end{array}$ & $\begin{array}{l}\text { Ummalyma } \\
\text { et al. (2017) }\end{array}$ \\
\hline
\end{tabular}

SS suspended solids, COD chemical oxygen demand, TOC total organic content, $D O C$ dissolved organic content

- Besides being natural and plentiful, this amino-polysaccharide also possesses other useful characteristics such as hydrophilicity, polyfunctionality, reactivity, complexing and adsorption properties.

- Due to their structure, e.g. high molecular weight, and chemical properties, e.g. high cationic charge, chitosan macromolecules promote both chemical coagulation, subsequent floc formation and sedimentation of colloidal particles and/or dissolved pollutants in the effluents through established processes such as charge neutralization, inter-particle bridging, and also adsorption. 
Table 9.3 Applications using bioflocculation by chitosan

\begin{tabular}{|c|c|c|c|}
\hline $\begin{array}{l}\text { Potential } \\
\text { application }\end{array}$ & Chitosan/Flocculation condition(s) & Pollution/Pollutant(s) & Reference \\
\hline Drinking water & $\begin{array}{l}\text { Modified: hydrochloride, acetate, } \\
\text { lactate }\end{array}$ & $\begin{array}{l}\text { Turbidity, viruses, } \\
\text { bacteria }\end{array}$ & $\begin{array}{l}\text { Abede et al. } \\
(2016)\end{array}$ \\
\hline $\begin{array}{l}\text { Municipal } \\
\text { wastewater }\end{array}$ & $\begin{array}{l}\text { Raw powder dissolved in } \mathrm{HCl} \\
\text { solution }\end{array}$ & $\begin{array}{l}\mathrm{Cu}, \mathrm{Pb}, \mathrm{Ni}, \mathrm{Zn} \text {, tur- } \\
\text { bidity, organic matter }\end{array}$ & $\begin{array}{l}\text { Hargreaves } \\
\text { et al. (2018) }\end{array}$ \\
\hline $\begin{array}{l}\text { Sanitary landfill } \\
\text { leachate }\end{array}$ & $\begin{array}{l}\text { Chitosan dissolved in } \mathrm{HCl} \text { solution } \\
\text { at } 960 \mathrm{mg} / \mathrm{L} ; \mathrm{pH} 8.5\end{array}$ & $\begin{array}{l}\text { Turbidity, SS, COD, } \\
\text { TOC, nitrite, nitrate, } \\
\text { color, phosphorus }\end{array}$ & $\begin{array}{l}\text { Nascimento } \\
\text { et al. (2016) }\end{array}$ \\
\hline $\begin{array}{l}\text { Drinking water } \\
\text { sludge }\end{array}$ & $\begin{array}{l}\text { Chitosan (DD 95\%)-aluminum } \\
\text { chloride in acetic acid solution; } \\
\text { pH } 8.4\end{array}$ & $\begin{array}{l}\text { Dewatering, extra- } \\
\text { cellular organic } \\
\text { matter }\end{array}$ & $\begin{array}{l}\text { Ma et al. } \\
(2016 a, b)\end{array}$ \\
\hline $\begin{array}{l}\text { Municipal acti- } \\
\text { vated sludge }\end{array}$ & $\begin{array}{l}\text { Powder }(\mathrm{DD}>75 \%) \text { dissolved in } \\
\text { acetic acid solution; } \mathrm{pH} 4\end{array}$ & $\begin{array}{l}\text { Dewatering, SS, } \\
\text { VSS, turbidity }\end{array}$ & $\begin{array}{l}\text { Zemmouri } \\
\text { et al. (2015) }\end{array}$ \\
\hline Lake restoration & $\begin{array}{l}\text { Raw powder dissolved in acetic } \\
\text { acid solution }\end{array}$ & Cyanobacteria & $\begin{array}{l}\text { Mucci et al. } \\
\text { (2017) }\end{array}$ \\
\hline River water & $\begin{array}{l}\text { DD 75-85\%; dosage of } 1 \mathrm{mg} / \mathrm{L} \text {; } \\
\text { pH } 6.7\end{array}$ & $\mathrm{~Pb}, \mathrm{Mn}$, turbidity & $\begin{array}{l}\text { Ruelas-Leyva } \\
\text { et al. (2017) }\end{array}$ \\
\hline Sea water & $\begin{array}{l}\text { Powder dissolved in acetic acid } \\
\text { solution; } 18 \mathrm{mg} / \mathrm{L} ; \mathrm{pH} 8.1\end{array}$ & Turbidity & $\begin{array}{l}\text { Altaher } \\
(2012)\end{array}$ \\
\hline Fishmeal industry & Chitosan: $\mathrm{pH} 6.5$, dose $300 \mathrm{mg} / \mathrm{L}$ & SS, VSS & $\begin{array}{l}\text { Arias- } \\
\text { Lizarraga and } \\
\text { Mendez- } \\
\text { Gomez (2014) }\end{array}$ \\
\hline Algal removal & $\begin{array}{l}\text { Quaternized carboxymethyl } \\
\text { chitosan }\end{array}$ & & $\begin{array}{l}\text { Dong et al. } \\
(2014)\end{array}$ \\
\hline Algal removal & $\mathrm{pH} 8.5$ & $\begin{array}{l}\text { Microalgae, cyano- } \\
\text { bacterium species }\end{array}$ & $\begin{array}{l}\text { Lama et al. } \\
\text { (2016) }\end{array}$ \\
\hline Algal removal & Chitosan-graft-polyacrylamide & $\begin{array}{l}\text { Algal colloid } \\
\text { particles }\end{array}$ & $\begin{array}{l}\text { Lu et al. } \\
(2017)\end{array}$ \\
\hline $\begin{array}{l}\text { Harvesting of } \\
\text { microalgae }\end{array}$ & $\begin{array}{l}\text { Flakes (DD: } 80 \% \text { ) dissolved in } \\
\text { acetic acid solution }\end{array}$ & Microalgae & $\begin{array}{l}\text { Gerchman } \\
\text { et al. (2017) }\end{array}$ \\
\hline $\begin{array}{l}\text { Harvesting of } \\
\text { microalgae }\end{array}$ & $\begin{array}{l}\text { Raw powder dissolved in } \mathrm{HCl} \\
\text { solution }\end{array}$ & $\begin{array}{l}\text { Microalgae suspen- } \\
\text { sion, COD }\end{array}$ & $\begin{array}{l}\text { Sajjad et al. } \\
(2017)\end{array}$ \\
\hline $\begin{array}{l}\text { Harvesting of } \\
\text { microalgae }\end{array}$ & $\begin{array}{l}\text { Chitosan: dose } 100 \mathrm{mg} / \mathrm{L} \text {; } \\
\text { pH 7-10 }\end{array}$ & BOD, COD & $\begin{array}{l}\text { Gupta et al. } \\
(2018)\end{array}$ \\
\hline $\begin{array}{l}\text { Flocculation of } \\
\text { microalgae in } \\
\text { seawater }\end{array}$ & $\begin{array}{l}\text { Chitosan (DD: }>75 \% \text {, dissolved in } \\
\mathrm{HCl} \text { solution): } \mathrm{pH}>7.5 \text {, dose } \\
75 \mathrm{mg} / \mathrm{L}\end{array}$ & $\begin{array}{l}\text { Marine microalgae, } \\
\mathrm{Mg}\end{array}$ & $\begin{array}{l}\text { Blockx et al. } \\
(2018)\end{array}$ \\
\hline $\begin{array}{l}\text { Aquaculture } \\
\text { wastewater from } \\
\text { catfish farming }\end{array}$ & $\begin{array}{l}\text { Raw powder dissolved in } \mathrm{HCl} \\
\text { solution }(1 \mathrm{~g} / \mathrm{L})\end{array}$ & Microalgae & $\begin{array}{l}\text { Yunos et al. } \\
\text { (2017) }\end{array}$ \\
\hline $\begin{array}{l}\text { Bacterial } \\
\text { suspensions }\end{array}$ & $\begin{array}{l}\text { Raw powder (DD: } 86.3 \% \text { ) } \\
\text { dissolved in } \mathrm{HCl} \text { solution }\end{array}$ & Cyanobacteria & $\begin{array}{l}\text { Lürling et al. } \\
\text { (2017) }\end{array}$ \\
\hline $\begin{array}{l}\text { Wastewaters } \\
\text { from a yeast } \\
\text { factory }\end{array}$ & $\begin{array}{l}\text { Modified chitosan; dose } 2 \text { or } 3 \mathrm{~g} / \mathrm{L} \text {; } \\
\text { pH } 3 \text { and } 7\end{array}$ & $\begin{array}{l}\text { Turbidity, SS, COD, } \\
\text { color }\end{array}$ & $\begin{array}{l}\text { Momemi et al. } \\
\text { (2018) }\end{array}$ \\
\hline
\end{tabular}


Table 9.3 (continued)

\begin{tabular}{|c|c|c|c|}
\hline $\begin{array}{l}\text { Potential } \\
\text { application }\end{array}$ & Chitosan/Flocculation condition(s) & Pollution/Pollutant(s) & Reference \\
\hline $\begin{array}{l}\text { Agricultural } \\
\text { wastewaters }\end{array}$ & $\begin{array}{l}\text { DD } 75-85 \% \text {; dosage of } 10 \mathrm{mg} / \mathrm{L} \text {; } \\
\text { pH } 6.6\end{array}$ & $\begin{array}{l}\text { Turbidity, } \\
\text { conductivity }\end{array}$ & $\begin{array}{l}\text { Ruelas-Leyva } \\
\text { et al. (2017) }\end{array}$ \\
\hline Tanning effluents & Raw product (DD: $85 \%)$ & $\begin{array}{l}\text { SS, COD, TOC, } \\
\text { BOD }\end{array}$ & $\begin{array}{l}\text { Sila et al. } \\
(2014)\end{array}$ \\
\hline $\begin{array}{l}\text { Effluents from } \\
\text { the sugar industry }\end{array}$ & $\begin{array}{l}\text { Powder dissolved in } \mathrm{HCl} \text { solution } \\
(138 \mathrm{mg} / \mathrm{L}) ; \mathrm{pH} 5\end{array}$ & SS, color, COD & $\begin{array}{l}\text { Pambi and } \\
\text { Musonge } \\
\text { (2015) }\end{array}$ \\
\hline $\begin{array}{l}\text { Palm oil mill } \\
\text { effluent }\end{array}$ & $\begin{array}{l}\text { Chitosan dissolved in acetic acid } \\
\text { solution }\end{array}$ & $\begin{array}{l}\text { BOD, COD, ammo- } \\
\text { nium nitrogen, Phos- } \\
\text { phate, potassium }\end{array}$ & $\begin{array}{l}\text { Tadza et al. } \\
\text { (2016) }\end{array}$ \\
\hline $\begin{array}{l}\text { Palm oil mill } \\
\text { effluent }\end{array}$ & $\begin{array}{l}\text { Powder (DD: } 90.1 \% \text { ) dissolved in } \\
\text { acetic acid solution }\end{array}$ & $\begin{array}{l}\text { Turbidity, COD, } \\
\text { hydrocarbon content }\end{array}$ & $\begin{array}{l}\text { Adnan et al. } \\
(2017)\end{array}$ \\
\hline $\begin{array}{l}\text { Emulsified oily } \\
\text { wastewater }\end{array}$ & $\begin{array}{l}\text { Flakes (DD: } 82.9 \% \text { ) dissolved in } \\
\text { acetic acid solution, dose } 0.793 \\
\mathrm{~g} / \mathrm{L}, \mathrm{pH} 4 \text { or } 7\end{array}$ & & $\begin{array}{l}\text { Pérez- } \\
\text { Calderón et al. } \\
(2018)\end{array}$ \\
\hline $\begin{array}{l}\text { Effluents } \\
\text { containing diesel } \\
\text { oil and gasoline }\end{array}$ & Powder dissolved in $\mathrm{HCl}$ solution & Turbidity, COD & $\begin{array}{l}\text { de Oliveira } \\
\text { et al. (2016) }\end{array}$ \\
\hline Brackish water & & SS, turbidity & $\begin{array}{l}\text { Lamia and } \\
\text { Abdelghani } \\
(2017)\end{array}$ \\
\hline Clay suspensions & $\begin{array}{l}\text { Powder dissolved in acetic acid } \\
\text { solution }\end{array}$ & $\mathrm{Cu}, \mathrm{Zn}$, turbidity & $\begin{array}{l}\text { Ferhat et al. } \\
(2016)\end{array}$ \\
\hline $\begin{array}{l}\text { Effluents } \\
\text { containing humic } \\
\text { substances }\end{array}$ & $\begin{array}{l}\text { Raw product (DD: } 90 \% \text { ) in acetic } \\
\text { acid solution; } \mathrm{pH} 7\end{array}$ & Humic acid, turbidity & $\begin{array}{l}\text { Chen et al. } \\
\text { (2015) }\end{array}$ \\
\hline $\begin{array}{l}\text { Effluents } \\
\text { containing dyes }\end{array}$ & Composite & Color, dyes & $\begin{array}{l}\text { Lou et al. } \\
(2018)\end{array}$ \\
\hline $\begin{array}{l}\text { Effluents } \\
\text { containing dyes }\end{array}$ & Copolymer with starch & Dyes & $\begin{array}{l}\text { Sami et al. } \\
\text { (2017) }\end{array}$ \\
\hline $\begin{array}{l}\text { Solutions } \\
\text { containing dyes }\end{array}$ & $\begin{array}{l}\text { Powder dissolved in } \mathrm{HCl} \text { solution } \\
(1 \mathrm{~g} / \mathrm{L})\end{array}$ & Dyes & $\begin{array}{l}\text { Wang et al. } \\
\text { (2017) }\end{array}$ \\
\hline $\begin{array}{l}\text { Plating } \\
\text { wastewater }\end{array}$ & Chitosan dianhydride & $\mathrm{Cu}, \mathrm{Pb}, \mathrm{Zn}, \mathrm{Ni}, \mathrm{Cr}$ & $\begin{array}{l}\text { Martinez- } \\
\text { Quiroz et al. } \\
(2018) \\
\end{array}$ \\
\hline $\begin{array}{l}\text { Effluents } \\
\text { containing metals }\end{array}$ & $\begin{array}{l}\text { Mercaptoacetyl chitosan (DD: } \\
80 \% \text { ); } \mathrm{pH} 4.5 ; \text { time } 2.5 \mathrm{~h}\end{array}$ & Copper, turbidity & $\begin{array}{l}\text { Zhang et al. } \\
(2015)\end{array}$ \\
\hline $\begin{array}{l}\text { Effluents } \\
\text { containing } \\
\text { palladium }\end{array}$ & $\begin{array}{l}\text { Sulphur-chitosan; } \mathrm{pH} 2-5.5, \text { dose } \\
0.8 \mathrm{~g} / \mathrm{L}\end{array}$ & Pd, metals & $\begin{array}{l}\text { Xie et al. } \\
(2018)\end{array}$ \\
\hline $\begin{array}{l}\text { Solutions } \\
\text { containing } \mathrm{Cr}(\mathrm{VI})\end{array}$ & Copolymer with starch & $\mathrm{Cr}(\mathrm{VI})$ & $\begin{array}{l}\text { You et al. } \\
(2016)\end{array}$ \\
\hline $\begin{array}{l}\text { Effluents } \\
\text { containing dyes } \\
\text { and metals }\end{array}$ & $\begin{array}{l}\text { Carboxylate-rich magnetic } \\
\text { chitosan }\end{array}$ & Dyes, metals & $\begin{array}{l}\text { Liu et al. } \\
(2018)\end{array}$ \\
\hline
\end{tabular}


Table 9.3 (continued)

\begin{tabular}{l|l|l|l}
\hline $\begin{array}{l}\text { Potential } \\
\text { application }\end{array}$ & Chitosan/Flocculation condition(s) & Pollution/Pollutant(s) & Reference \\
\hline $\begin{array}{l}\text { Effluents } \\
\text { containing } \\
\text { plastics }\end{array}$ & $\begin{array}{l}\text { Powder (DD: 60\%) dissolved in } \\
\text { HCl solution }(0.1 \mathrm{~g} / \mathrm{L})\end{array}$ & Polystyrene & $\begin{array}{l}\text { Ramirez et al. } \\
(2016)\end{array}$ \\
\hline $\begin{array}{l}\text { Solutions } \\
\text { containing } \\
\text { antibiotics }\end{array}$ & Amino-acid-modified chitosan & $\begin{array}{l}\text { Antibiotics, SS, } \\
\text { organic matter }\end{array}$ & $\begin{array}{l}\text { Jia et al. } \\
(2016)\end{array}$ \\
\hline $\begin{array}{l}\text { Dissolved air flo- } \\
\text { tation process for } \\
\text { river water } \\
\text { treatment }\end{array}$ & $\begin{array}{l}\text { Powder (DD: } 87.8,76.5 \text { and } \\
\text { dissolved in HCl solution } \\
(1 \mathrm{~g} / \mathrm{L} ; \mathrm{pH} 7)\end{array}$ & $\begin{array}{l}\text { Turbidity, SS, TOC, } \\
\text { organic matter }\end{array}$ & $\begin{array}{l}\text { Shi et al. } \\
(2017)\end{array}$ \\
\hline
\end{tabular}

$D D$ degree of deacetylation, $S S$ suspended solids, $C O D$ chemical oxygen demand, $B O D$ biochemical oxygen demand, TOC total organic carbon, VSS volatile suspended solids, MW molecular weight

Table 9.4 Main characteristics and properties of chitosan in relation to its use for flocculationbased application

Main characteristics and properties

Raw chitosan for water treatment applications: low-cost product (chitin: renewable resource obtained from byproducts)

Non-toxic, biocompatible and biodegradable substance

Ecofriendly biopolymer; ecologically acceptable product

Linear amino-polysaccharide with high nitrogen content; weak base and powerful nucleophile

Hydrophilic biopolymer with high reactivity

Reactive amino and hydroxyl groups for modification

Polyelectrolyte at acidic $\mathrm{pH}$ with high charge density: polycationic biopolymer

Ionic conductivity

Gelation ability; adhesivity; film-forming ability

Ability to form hydrogen bonds and other noncovalent interactions

Ability to encapsulate; entrapment properties

Chelation, ion-exchange and adsorption properties

Removal of pollutants or pollutions (color, odor) with outstanding performance

Strong adsorption to negative microalgae cells; since the products work as a function of surface charge, the required dosage increases proportionately to microalgae concentration

Formation of salts with organic and inorganic acids

Efficient against bacteria, viruses and fungi

Chitosan is less sensitive to $\mathrm{pH}$ changes than metal salts

Chitosan has been shown to coagulate microalgae cells very effectively and to produce larger flocs than polyaluminium chloride

References: Skjåk-Braek et al. (1989), Roberts (1992), No and Meyers (1995), Peters (1995), Goosen (1997), Kurita (1998, 2006), Ravi Kumar (2000), Domard and Domard (2001), Dutta et al. (2004), Vårum and Smidsrød (2004), Rinaudo (2006), Li et al. (2008), Crini et al. (2009a, b), de Alvarenga (2011), Sudha (2011), Nwe et al. (2011), Teng (2016), Nechita (2017) 
- Chitosan has demonstrated outstanding performance, not only for the elimination of particulate pollutants, i.e. suspended solids and colloids, but also for the removal of dissolved pollutants, even at ultra-trace levels. This product is efficient towards very fine particles. The cationic amino groups on the chitosan chains facilitate their chemical interaction (attraction phenomenon, adsorption) with negatively charged colloids, such as viruses, bacteria and clay turbidity, thereby promoting their coagulation-flocculation and sedimentation, and also pollutant removal by adsorption. Chitosan produces a high-quality pretreated or treated effluent. The alkalinity is also maintained.

- Chitosan can be used over a wide range of temperatures. It is efficient in cold water and at much lower concentration than metal salts.

- The lower concentration reduces the volume of sludge production compared to sludge obtained with polyaluminium chloride. The sludge can be degraded by microorganisms.

- Compared with conventional chemical reagents, chitosan produces no secondary pollution. There are no residuals or metals added such as $\mathrm{Al}(\mathrm{III})$ and $\mathrm{Fe}(\mathrm{III})$.

\subsubsection{Limitations of Using Chitosan as Bioflocculant}

Table 9.5 describes the main disadvantages of chitosan used as bioflocculants. They can be summarized as follows:

- Despite a large number of studies on the use of chitosan for bioflocculation in the literature, this research field has failed to find practical applications on the

Table 9.5 Disadvantages of chitosan-based bioflocculants for water and wastewater treatments applications

Technologies are still being developed: to be confirmed at scale up levels

The cost limitations still exist: chitosan is considered cost prohibitive to purchase for use as an microalgae bioflocculant

Chitosan is not water-soluble: it requires a weak acid treatment to be dissolved; the solubility depends on the degree of deacetylation and molecular weight parameters

Variability in the chitosan characteristics and in the materials used; performances depend on type of raw chitosan, chitosan activation and chitosan-based materials

Chitosan is a very efficient flocculant but at low $\mathrm{pH}$; $\mathrm{pH}$-dependent behavior

The dosage used is in general high; chitosan concentration should be monitored to avoid restabilization (due to excess cationic charge if a high concentration is used)

Possible clogging of filters when the doses of chitosan are high

Chitosan requires chemical modification to improve its performance, to decrease its $\mathrm{pH}$ sensitivity, and to enlarge the field of its potential applications; results depend on the functional groups grafted

Bioflocculation using chitosan is not universal to all pollutant types; e.g. it was found effective for green microalgae but gave poor results for cyanobacteria

References: Crini et al. (2009a, b); Renault et al. (2009a, b, c, d); Ujang et al. (2011); Lee et al. (2014); Yang et al. (2016); Sudha et al. (2017) 
industrial scale. Indeed, aside from a few pilot studies in aquaculture or in target applications, e.g. recovery of precious metals, bioflocculation using chitosan is at the stage of laboratory-scale study in water and wastewater treatments.

- It is difficult to get reproducible initial chitosan, i.e. product quality control, and there is a need for a better standardization of the production process. Chitosan is a polysaccharide composed by macromolecules of D-glucosamine and $\mathrm{N}$-acetyl glucosamine. The chitosan label generally corresponds to products with less than $40 \%$ acetyl content. So, each commercial chitosan is a copolymer characterized by its average degree of acetylation or degree of deacetylation. Both parameters vary with the source of the raw materials and the preparation method.

- The degree of deacetylation and molecular weight parameters are important factors because they influence the physical and chemical properties of chitosan, particularly its solubility.

- Changes in the specifications, e.g. degree of deacetylation, molecular weight, of the chitosan may significantly change flocculation performance. The higher the quality, the greater the cost.

- A direct comparison of data obtained using different chitosans is difficult to make because of inconsistencies in the data presentation, e.g. specifications of chitosan, used experimental conditions of the effluents treated.

- Performance is dependent on the characteristics of the wastewater. In particular, uptake is strongly pH-dependent. Chitosan is a very efficient flocculant but it works at low $\mathrm{pH}$. For target applications such as in the microalgae culture fields where $\mathrm{pH}$ is generally high, it requires chemical modification.

- Chitosan also requires chemical derivatization such as grafting reactions or modifications (composite or hybrid materials) to improve its performance, to decrease its $\mathrm{pH}$ sensitivity or to enlarge the field of its practical applications. The flocculation performance depends on the different types of material used. For grafted polymer materials, the performance results were found to be a function not only of the nature of the ligands but also of the degree of attachment of the polyfunctional groups. So, the properties of the materials can be varied extensively.

All these reasons can explain why it is difficult to transfer the flocculation process to industrial scale. In addition, a direct comparison of data obtained in the literature using different chitosan-based materials is not possible since experimental conditions are not systematically the same. Comparisons among different commercial flocculants are also scarce. Cost is also an important parameter for comparing the materials. Due to scarcity of consistent information, cost comparisons are also difficult to make.

\subsubsection{Mechanism}

Similar to classical flocculation, bioflocculation by chitosan involves combining insoluble particles and dissolved organic matter into larger aggregates which can 


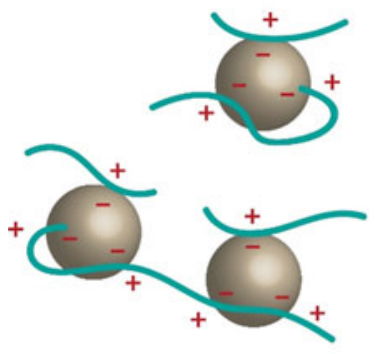

a

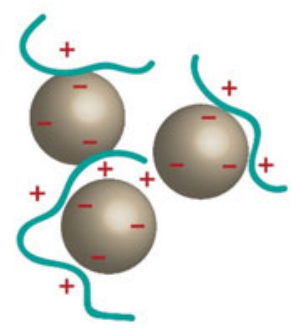

c

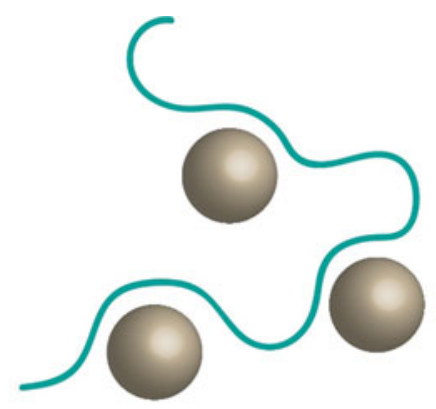

b

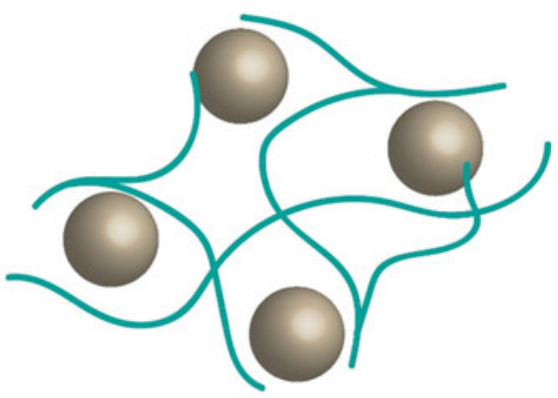

d

Fig. 9.4 Bioflocculation mechanism; (a) charge neutralization, (b) bridging, (c) electrostatic patch and (d) sweeping

be removed in subsequent sedimentation and filtration stages. Chitosan chains first destabilize suspended and colloidal particles in wastewater by forming micro-flocs in the coagulation step. These are then aggregated in the flocculation step, which consists of an agitation procedure that encourages particles to clump allowing their removal in subsequent treatment stages. The mechanism is well-known (Fig. 9.4), mainly driven by charge neutralization and bridging mechanisms. Other mechanisms such as electrostatic patch and sweeping mechanisms adsorption, entrapment, and complexation, chelation, and precipitation processes may also contribute to bioflocculation.

Charge neutralization refers to the interaction of two particles with opposite charged ions, whereas sweep flocculation entails the enmeshment of particles in a growing precipitate. Polymer chains agglomerate particles by inter-particle bridging. This phenomenon involves the adsorption of particles onto polymer chains by forming particle-polymer-particle complexes. The loops and tails of adsorbed polymer chains can protrude and attach to other particles in the medium, allowing bridging of particles to occur. This accounts for the fact that chitosan has the ability 
to enhance dissolved pollutant removal such as metal ions. Electrostatic patch is caused by polymer chains of high charge density interacting with oppositely charged colloidal particles of low charge density. The net residual charge of the polymer patch on one colloidal particle surface can adsorb onto the oppositely charged colloidal particle. Chitosan forms a bulky precipitate that enmeshes the colloidal particles (sweeping mechanism). These particles are then settled out or they flocculate together with the precipitate.

\subsubsection{Control of Bioflocculation Performance of Chitosan}

The main factors that affect coagulation are the characteristics of the solid materials, e.g. particle size and surface charge, the polyelectrolyte, e.g. charge density, molecular weight and hydrophobicity, the water chemistry, in particular $\mathrm{pH}$ and ionic strength, and the coagulation regime, e.g. concentration and agitation. Factors affecting flocculation are primarily polymer type, e.g. molecular weight, degree of deacetylation and charge density, ionic strength, water $\mathrm{pH}$, slurry solids, flocculant dilution, shear, and process conditions such as flocculation behavior, e.g. sedimentation velocity, packing density of the sludge and particle size distribution (Stechemesser and Dobiáš 2005; Abebe et al. 2016).

Bioflocculation is a time-dependent process that directly affects clarification efficiency by providing multiple opportunities for particles suspended in aqueous solutions to collide through gentle and prolonged agitation. Similar to flocculation that uses conventional polymers, the process is complex that involves several steps or sub-processes that occur sequentially or concurrently, where its behavior is critically dependent on the physicochemical characteristics of the reagents used. During the process, the mixing of particles and polymers in solution, adsorption of the polymer on the surface of particles, re-conformation of adsorbed polymer chains on the surface, aggregate formation, breakage of flocs by shear, restructuring of flocs, re-flocculation of broken flocs, desorption of polymer under high shear and sedimentation or creaming of flocs take place simultaneously. Agitation should be thorough enough to encourage inter-particle contact but gentle enough to prevent disintegration of existing flocculated particles or flocs. Flocs grow by colliding with other particles, and sticking together. Time is an important factor for the formation of flocs. The longer the time, the larger the floc. Solution $\mathrm{pH}$ is another important variable in flocculation because it affects the electrochemical nature of both the components. A comprehensive discussion on these topics can be found in the book by Stechemesser and Dobiáš (2005). 


\subsection{Chitosan for Direct Bioflocculation: Potential Applications}

\subsubsection{Palm Oil Mill Effluent}

The main problem with palm oil producing countries are commonly associated with the production of palm oil mill effluent. In Malaysia alone, it is estimated that approximately, 50-75 million tons of palm oil mill effluent were produced annually (Ding et al. 2016). The effluent is a thick brownish colloidal mixture of different element including water, oil and suspended particles (Bala et al. 2015). Freshly generated palm oil mill effluent is usually discharged at temperature between 80 and $90{ }^{\circ} \mathrm{C}$ and is acidic in nature, having an average $\mathrm{pH}$ value of about 4.5. The dark liquid typically contains substantial amount of suspended solids, oil and grease and have high concentrations of biochemical oxygen demand as well as chemical oxygen demand. Table 9.6 presents typical characteristics of raw and treated palm oil mill effluent.

Illegal discharge of raw or partially treated palm oil mill effluent into nearby water bodies or land is common and still being practiced, as this is the easiest and cheapest option for disposal (Tadza et al. 2015). However, due to strict regulatory discharge limits and increasing environmental awareness, palm oil mill effluent is now treated prior to being discharged into the environment. Currently, integrated biological with physicochemical methods are commonly used for the treatment of raw effluent. Since the effluent is largely biodegradable, biological treatment appears to be the most viable treatment method. In this case, open aerobic or anaerobic ponding systems are opted over the years. Ironically, the final discharged effluents

Table 9.6 Typical characteristics of raw and treated palm oil mill effluent and discharge limits

\begin{tabular}{|c|c|c|c|c|}
\hline Parameters & Unit & Raw effluent & Treated effluent & Discharge limits \\
\hline $\mathrm{pH}$ & & 4.2 & 8.4 & $5.0-9.0$ \\
\hline Temperature & ${ }^{\circ} \mathrm{C}$ & $85-90$ & $25-30$ & 45 \\
\hline COD & $\mathrm{mg} / \mathrm{L}$ & 50,000 & 4500 & - \\
\hline BOD & $\mathrm{mg} / \mathrm{L}$ & 35,000 & 450 & 100 \\
\hline Oil, grease & $\mathrm{mg} / \mathrm{L}$ & 6000 & - & 50 \\
\hline $\mathrm{TS}$ & $\mathrm{mg} / \mathrm{L}$ & 40,000 & - & 1500 \\
\hline TSS & $\mathrm{mg} / \mathrm{L}$ & 18,000 & 130 & 400 \\
\hline $\mathrm{NH}_{4}-\mathrm{N}$ & $\mathrm{mg} / \mathrm{L}$ & 180 & 20 & 100 \\
\hline $\mathrm{PO}_{4}{ }^{3-}$ & $\mathrm{mg} / \mathrm{L}$ & 210 & - & - \\
\hline Turbidity & NTU & 430 & 100 & - \\
\hline Color & $(\mathrm{PtCo})$ & 32,000 & 250 & - \\
\hline
\end{tabular}

References: Wu et al. (2010), Chan et al. (2011), MPOB (2012), Bello et al. (2013), Bala et al. (2015), Tadza et al. (2015, 2016), Saeed et al. (2016)

$C O D$ chemical oxygen demand, $B O D$ biochemical oxygen demand, TSS total suspended solids 
from these conventional ponding systems often failed to conform to regulatory discharge limits (Rushdy et al. 2014; Bello and Raman 2017). Furthermore, removal of compound, i.e. lignin-tannin, that is responsible for the dark coloration of palm oil mill effluent, is recalcitrant to biological treatment and should be further treated using different secondary treatment or polishing methods.

To date, the use of chitosan in the treatment of palm oil mill effluent appears to be very limited. Chitosan and its derivatives have been tested to be effective coagulation agents in treating raw and treated palm oil mill effluents. For instance, Ahmad et al. $(2005 \mathrm{a}, \mathrm{b})$ noted that powdered and flake chitosan is effective in removal of solids (> 90\%) and residual oil (> 95\%) from palm oil mill effluent. The results showed that chitosan performed better compared to other natural absorbents such as bentonite, zeolite and activated carbon. The performance of chitosan was better than that of alum and polyaluminum chloride. The removal of residual oil and reduction in the total solid concentrations in palm oil mill effluent is $\mathrm{pH}$ dependent. The removal efficiency is reduced with increasing $\mathrm{pH}$ values. Palm oil mill effluent strong acidic conditions enhances the coagulation of the oil residue in the effluent. Under acidic conditions, chitosan provokes a physico-chemical effect, serves as a demulsifying agent and enhances the adsorption of oil and grease (Ahmad et al. 2005a). It is believed that the availability of proton increased to protonate amine groups of chitosan molecules. On the other hand, adsorptive removal of heavy metals using chitosan alone has not been very successful.

Apart from powdered and flakes of chitosan, the derivatives of chitosan were also used to treat palm oil mill effluents. This involves dissolving powdered chitosan with an acidic solution (Ahmad et al. 2006; Torres et al. 2018). In some cases, chitosan is mixed with other oxidative chemicals such as ferric chloride, ferrous sulfate and hydrogen peroxide (Parthasarathy et al. 2016; Tadza et al. 2016). These studies showed improved solids removal and significant increase in the removal efficiency of chemical oxygen demand compared to using powdered chitosan alone. Based on these studies, chitosan coagulation coupled with hydrogen peroxide proves to be a better alternative for the post-treatment of anaerobically digested palm oil mill effluent due to its improved treatment efficiency, environmental safety and availability. Although no explanation was made on the possible reasons for this observation, it is anticipated that the neutral $\mathrm{pH}$ considered or the possible interaction between iron and chitosan which might lead to the reduction of active sites of the iron (Bello and Raman 2017).

Although chitosan has shown remarkable performance in treating palm oil mill effluents, the palm oil mills have been complaisant with the ponding system due to its simplicity and cost effectiveness. Consequently, almost all studies mentioned were conducted under small scale laboratory conditions. Feasibility studies are yet to be put to large scale applications. Despite chitosan reported potentials, a lot of effort is required in upscaling these technologies to the industrial level. Another challenge would be dealing with sludge generated as by-product of coagulation process using chitosan. Tadza et al. (2016) showed that the sludge displayed good fertility characteristics and may be considered as fertilizer or soil conditioners in the future. 


\subsubsection{Effluents from the Sugar Industry}

Pambi and Musonge (2015) studied the efficiency of chitosan as a coagulant in the treatment of the effluents from the sugar industry to remove both suspended solids, color and chemical oxygen demand. The sugar refinery consumes large amounts of water daily and approximately $47 \%$ of this water is discharged as wastewater. The treatment of effluents by chitosan was investigated under varying chitosan dosage with a study of the effect of $\mathrm{pH}$ on impurity removal performance. It was found that an increase in the chitosan dosage increased the impurity removal efficiency for the response variables investigated. However, beyond the optimum coagulant concentration, no further improvement was observed. The optimum chitosan loading was found to be $138 \mathrm{mg} / \mathrm{L}$. The impurity content in the effluent was found to influence the amount of chitosan loading required. High removal efficiencies were achieved under acidic conditions, due to the cationic nature of chitosan. However, the removal of chemical oxygen demand was very low due to the fact that most of the matter present in the effluent was related to dissolved organics. The performance of the chitosan was found to be $\mathrm{pH}$-dependent. Using sodium hydroxide to adjust the $\mathrm{pH}$ to higher values strongly affected the performance of the chitosan in a negative way, due to its possible gelation at such alkaline conditions. Overdosing the coagulant destabilized the neutralized flocs and impeded their settling. The mechanism was explained in further detail as follows: firstly the cationic charge of the protonated macromolecule destabilized and neutralized the anionic charges of the impurities; secondly, there was bridging of the macromolecules with the particles leading to flocs formation; and finally electrostatic patch occurs, as described above. Chitosan serves a dual role, both as a coagulant and flocculant by virtue of its charge density and relatively high molecular weight. The authors concluded that chitosan as low-cost biodegradable material was an ideal candidate to substitute conventional synthetic materials.

\subsubsection{Agricultural Wastewater}

Chitosan can be an alternative for the treatment of effluents containing residual fertilizers and pesticides such as herbicides that trigger the pollution of diverse segments of the environment, including rivers used for drinking water production. Specially, for pesticides that persist for many years, where it is necessary for the removal of these chemicals from contaminated water bodies. As an example, organochlorines pesticides are highly hazardous and have reluctant chemical structures to exhibit degradation. In this field, there is still a demand for efficient methods to be developed and applied at an industrial scale, as recently pointed out by Rani et al. (2017).

Rahmanifar and Moradi-Dehaghi (2014) carried out interaction tests among chitosan and permethrin, an organochlorine pesticide. Batch trials were performed 
at $\mathrm{pH} \mathrm{7,} \mathrm{under} \mathrm{shaking} \mathrm{at} 150 \mathrm{rpm}$ for time of $45 \mathrm{~min}$, with prescribed amount of chitosan within the range from 0.01 to $1.5 \mathrm{~g}$ added to $25 \mathrm{~mL}$ of a prepared permethrin solution $(0.1 \mathrm{ppm})$. The adsorption efficiency increased with the higher adsorbent concentration up to $0.5 \mathrm{~g}$. Thereafter, the adsorbent dose did not play an important role, and nearly $50 \%$ removal was reached for dosages between 0.5 and $1.5 \mathrm{~g}$. The entrapment of the model pesticide was markedly improved (near to 98\%) when a nanocomposite form of chitosan- $\mathrm{AgO}$ was the adsorbent.

In another contribution (Shankar et al. 2018), the removal of pentachlorophenol, a common pesticide, from aqueous solutions was assessed by comparing chitosan versus modified chitosan: [chitosan-(2-hydroxy-1-naphthaldehyde)]. The effect of contact time on pesticide adsorption was studied, based on experiments in batch mode, under stirring, where $0.2 \mathrm{~g}$ of adsorbent were added to $200 \mathrm{~mL}$ of a synthetic solution containing pesticide $(150 \mathrm{mg} / \mathrm{L})$. Data showed fast initial removal, which was related to the availability of vacant sites for adsorbent-pesticide interactions. From $60 \mathrm{~min}$, the maximum adsorption capacity was practically reached for both of the biosorbents. The adsorption capacity exhibited by chitosan $(24.4 \mathrm{mg} / \mathrm{g})$ at neutral $\mathrm{pH}$ was enhanced by $94 \%$ using the modified form. The adsorption capacity decreased with rising the $\mathrm{pH}$ from 3.0 to 8.0 (higher contaminant solubility; $\mathrm{pK}_{\mathrm{a}}=4.7$ ), as well as for higher temperatures in the range of $293-313 \mathrm{~K}$ for the unmodified and modified forms of chitosan.

In the case of other chemical families, model wastewaters containing the commercial pyrethroid and dithiocarbamate pesticides were selected to be treated for removal by employing chitosan (Ghimici et al. 2016). These tests led to a similar maximum removal efficiency (nearly 90\%), irrespective of the pesticide type. Chitosan showed good flocculation at low doses from 1 to $3.4 \mathrm{mg} / \mathrm{L}$ for $\alpha$-cypermethrin, deltamethrin and mancozeb as active ingredients, and the analysis of zeta potential measurements suggested that the flocculation of particles took place mainly via the charge neutralization mechanism. Naturally, the behavior of the treatment process can be significantly different when synthetic samples are compared with samples taken from agricultural effluents, because of the wide variety of pollutants deposited in raw water.

Nevertheless, Ruelas-Leyva et al. (2017) proved the high efficiency of chitosan in turbidity removal using samples of raw agricultural wastewater with $36 \mathrm{NTU}$ and $\mathrm{pH}$ conditions close to 7.5. Experiments involved the direct bioflocculation process starting with stirring at $100 \mathrm{rpm}$ for $5 \mathrm{~min}$, afterward $60 \mathrm{rpm}$ for $30 \mathrm{~min}$, and then 30 min of undisturbed settling; the $\mathrm{pH}$ of samples was not manipulated. From the results, it was found that an increase in the chitosan dosage resulted in higher turbidity reduction, and after a given dosage $(10 \mathrm{mg} / \mathrm{L})$ the remaining turbidity was constant $(<5 \mathrm{NTU})$. In this study, the removal mechanism was sweep flocculation. Additional experiments regarding detection and removal of particular chemical substances were not described. According to our literature review, it is required more comprehensive experiments using chitosan for the remediation of raw agricultural wastewater, where the efficiency of the simultaneous removal of residual fertilizers, pesticides such as fungicides and herbicides, should be addressed. 


\subsubsection{Pretreatment of Seawater}

One of the problems that encounters the desalination industry is the fouling that takes place due to the poor quality of the influent sea water received for treatment, especially when it rains. In such a situation, the sea water reaches the desalination plant having high turbidity. Altaher (2012) studied the removal of the turbidity of sea water by chitosan. The results demonstrated that chitosan dissolved in hydrochloric acid was efficient to remove turbidity from sea water in alkaline medium. The final turbidity of the sea water after treatment followed by conventional sand filtration was very low (0.433 NTU). The following conditions were used: optimum dose $18 \mathrm{mg} / \mathrm{L}$ (compared to $1200 \mathrm{mg} / \mathrm{L}$ for alum) with $250 \mathrm{rpm}$ of rapid stirring for $5 \mathrm{~min}, 30 \mathrm{~min}$ of slow stirring at $50 \mathrm{rpm}$, followed by $30 \mathrm{~min}$ of settling. The turbidity removal efficiency of chitosan dissolved in $\mathrm{HCl}$, chitosan dissolved in acetic acid, alum, and ferric chloride were $97.6 \%, 86.9 \%, 98 \%$, and $90 \%$, respectively. The turbidity removal efficiency of chitosan dissolved in hydrochloric acid was high compared to that obtained from chitosan dissolved in acetic acid. The performance of chitosan was better than that of ferrous sulfate but comparable to alum. The results were explained by charge neutralization and bridging mechanisms. The author also suggested that chitosan initially dissolved in acid media could precipitate when diluted into alkaline solutions. This precipitation process may be responsible for the removal of suspended solids due to the presence of a sweeping action. Throughout the experiments, no $\mathrm{pH}$ adjustment was required since chitosan performed well even in the alkaline $\mathrm{pH}$ of sea water. The main effect on performance depends on the molecular weight of the chitosan. Altaher (2012) concluded that chitosan might would be a potential replacement for metal coagulants due to its high turbidity removal efficiency even at high $\mathrm{pH}$ of treated water, availability, and safe usage.

\subsubsection{Amphoteric Chitosan for Phosphate Removal}

The fate and transport of oxoanion species such as orthophosphate $\mathrm{P}_{\mathrm{i}}$ in aquatic environments is a concern for human and ecosystem health due to the effects of eutrophication and excessive algae growth, as described in detail elsewhere (see Agbovi and Wilson 2017; Agbovi et al. 2017). While the use of synthetic flocculants offers an approach for the controlled removal of anion species in water and wastewater, there are concerns over the toxicity and secondary pollution effects arising from the use of potentially harmful organics such as polyacrylamide and metal species such as aluminum sulfate or alum for coagulation-flocculation processes. Based on the inspiration gained from the seminal contributions reported by Crini and coworkers, along with Renault et al. (2009a, b, c, d), Wilson' group has developed an interest in the potential use of chitosan as an alternative biopolymer versus synthetic coagulant-flocculant systems. As outlined above, chitosan has been reported to have dual function as a coagulant or flocculant system due to its 
polycation character at $\mathrm{pH}$ conditions near or below its $\mathrm{pK}_{\mathrm{a}}$ (ca. 6.3), along with its unique properties as a biopolymer material. Commercially available chitosan typically has degree of deacetylation values ca. $75-85 \%$ with a variable $\mathrm{pK}_{\mathrm{a}}(\approx 5.5-6.5)$ that depends on its molecular weight and degree of deacetylation value (Muzzarelli 1973). Depending on the $\mathrm{pH}$ of the medium, chitosan may possess "amphoteric-like" properties that are advantageous for application in flocculation-coagulation processes. This is in accordance with the protolytic equilibria of chitosan and the key role of acid additives, inorganic or organic, to aid in its dissolution in aqueous media. The unique polycation nature of chitosan has led to its utility as a versatile flocculant-coagulant for destabilization of colloidal dispersions, especially those with negative ionic charge or negative zeta-potential since a key step in the overall coagulation-flocculation process involves charge neutralization, as outline above.

From the viewpoint of water treatment processes, anion removal in water and wastewater treatment is a key challenge that differs uniquely from the removal of cation species, as described in detail elsewhere (Wilson et al. 2013; Steed and Atwood 2009). While the efficacy of soluble chitosan as a complexing agent for anions is well established as for flocculation-coagulation processes, the conditions are often restricted to acidic $\mathrm{pH}$ values. The addition of acid species to help dissolution of chitosan can be overcome via synthetic modification of chitosan amphoteric derivatives by functionalization of the $-\mathrm{OH}$ or $-\mathrm{NHR}(\mathrm{R}=\mathrm{H}$ or acetyl) groups of chitosan, according to its degree of deacetylation. One approach is to functionalize chitosan with anionic groups, such as $-\mathrm{R}^{\prime} \mathrm{CO}_{2} \mathrm{H},-\mathrm{R}^{\prime} \mathrm{PO}_{3} \mathrm{H}_{2},-\mathrm{R}^{\prime} \mathrm{SO}_{3} \mathrm{H}$, etc. where $\mathrm{R}^{\prime}=$ alkyl or aromatic linker of variable size, at the $-\mathrm{NHR}$ or $-\mathrm{OH}$ sites (Yang et al. 2016). To achieve permanent cationic character that is $\mathrm{pH}$ independent, chitosan can be functionalized with quaternary ammonium groups, such as $-\mathrm{NR}_{3}{ }^{+}$ where $\mathrm{R}=$ alkyl, at the $-\mathrm{OH}$ or $-\mathrm{NHR}$ sites ( $c f$. Tables 3.3 and 3.5 in Yang et al. 2016). A second strategy is to use mixtures of cationic and/or anionic flocculants along with/without an additive metal salt coagulant. Such types of mixtures impart "amphoteric" properties via blending of components in binary and ternary mixtures, as reported by (Agbovi and Wilson 2017; Agbovi et al. 2017). Table 9.7 lists some selected examples that can be drawn from studies of biopolymer flocculants such as alginate, polydiallyldimethyl-ammonium chloride, chitosan and its modified forms for the removal of orthophosphate $P_{i}$ species from synthetic and real wastewater. Additional examples of chitosan-based amphoteric flocculants are described elsewhere (Muzzarelli 1988; Meera and Emilia 2006; Prado and Matulewicz 2014; Quinlan et al. 2015; Besse et al. 2016; Kadokawa 2018).

According to Table 9.7, the efficacy of biopolymer flocculant-coagulant systems for the removal of orthophosphate $\mathrm{P}_{\mathrm{i}}$ is compared for the results reported by Wilson's group (Agbovi et al. 2017; Agbovi and Wilson 2017) and others. While variable removal efficiency of orthophosphate $P_{i}$ was achieved, where it is noted that the sole use of metal species, e.g. $\mathrm{Al}^{3+}$ or $\mathrm{Fe}^{3+}$, or biopolymer flocculants, such as alginate or chitosan, show differences according to the relative dosage and $\mathrm{pH}$ conditions. The combined use of metal ion species and its resulting influence on the adsorption properties of chitosan has been described in a recent report by Rashid et al. (2018) in a study of the adsorption properties of chitosan with 
Table 9.7 Selected studies of phosphate removal efficiency in water and wastewater for different types of coagulant-flocculant systems

\begin{tabular}{l|l|l|l|l|l}
\hline $\begin{array}{l}\text { Water } \\
\text { source }\end{array}$ & $\begin{array}{l}\text { Flocculant } \\
\text { system }\end{array}$ & $\begin{array}{l}\text { Optimum dosage } \\
(\mathrm{mg} / \mathrm{L})\end{array}$ & $\begin{array}{l}\text { Optimum } \\
\mathrm{pH}\end{array}$ & $\begin{array}{l}\text { Efficiency } \\
(\%)\end{array}$ & References \\
\hline SW & Alginate & 25 & $5.7-7.0$ & 38 & $\begin{array}{l}\text { Agbovi and Wil- } \\
\text { son (2017) }\end{array}$ \\
\hline SW & Alum/alginate & $30 / 59$ & $5.7-7.0$ & 80 & $\begin{array}{l}\text { Agbovi and Wil- } \\
\text { son (2017) }\end{array}$ \\
\hline SW & Fe(III)-alginate & 10 & 4.7 & 99.7 & $\begin{array}{l}\text { Agbovi and Wil- } \\
\text { son (2017) }\end{array}$ \\
\hline SW & Ferric chloride & 80 & 7.2 & 82 & Yang et al. (2010) \\
\hline RW & $\begin{array}{l}\text { Chitosan and } \\
\text { alginate }\end{array}$ & 10,20 & N/A & 80 & $\begin{array}{l}\text { Latifian et al. } \\
(2014)\end{array}$ \\
\hline SW & Chitosan & N/A & $7.5-7.9$ & 60 & Fierro et al. (2008) \\
\hline SW & $\begin{array}{l}\text { Chitosan } \\
\text { N/A }\end{array}$ & 4 & 30 & $\begin{array}{l}\text { Filipkowska et al. } \\
(2014)\end{array}$ \\
\hline SW & PDDMAC & 0.5 & 8 & 59 & $\begin{array}{l}\text { Chen and Luan } \\
(2010)\end{array}$ \\
\hline MW & Chitosan & 60 & 9.5 & 89 & $\begin{array}{l}\text { Dunets and Zheng } \\
(2015)\end{array}$ \\
\hline SEW & Alum & 10 & $5.7-5.9$ & 92 & Banu et al. (2007) \\
\hline SW & CMC-Fe(III) & 5 & 4 & 67.4 & $\begin{array}{l}\text { Agbovi and Wil- } \\
\text { son (2018) }\end{array}$ \\
\hline SW & $\begin{array}{l}\text { Chitosan-Fe } \\
\text { (III) }\end{array}$ & 10 & 4 & 90.6 & $\begin{array}{l}\text { Agbovi and Wil- } \\
\text { son (2018) }\end{array}$ \\
\hline SW & $\begin{array}{l}\text { CMC-CTA/Fe } \\
\text { (III) }\end{array}$ & 10 & 4 & 93.4 & $\begin{array}{l}\text { Agbovi and Wil- } \\
\text { son (2018) }\end{array}$ \\
\hline
\end{tabular}

$S W$ synthetic wastewater, $M W$ municipal wastewater, $R W$ real wastewater, $S E F$ secondary effluent wastewater, $P D D M A C$ polydiallyldimethyl-ammonium chloride

Reactive Black 5 and other dyes. In the case of polydiallyldimethyl-ammonium chloride, a relatively low flocculant dosage $(0.5 \mathrm{mg} / \mathrm{L})$ was used, where relatively high orthophosphate $\mathrm{P}_{\mathrm{i}}$ is noted. The effective removal for polydiallyldimethylammonium chloride is understood on the basis of high binding affinity between polyelectrolytes of opposite ionic charge. The dianion form of orthophosphate $\mathrm{P}_{\mathrm{i}}$ exists at this alkaline $\mathrm{pH}$ condition, according to the known $\mathrm{pK}_{\mathrm{a}}$ values for orthophosphate, i.e. $\mathrm{pK}_{\mathrm{a}, 1}=2.17, \mathrm{pK}_{\mathrm{a}, 2}=7.31$ and $\mathrm{pK}_{\mathrm{a}, 3}=12.36$ (Wilson and Tewari 2018). In contrast, the flocculation of other systems in Table 9.7 reported by Agbovi and Wilson were carried out at $\mathrm{pH} 4-5$, where the monoanion $\mathrm{P}_{\mathrm{i}}$ species prevails (Agbovi et al. 2017; Agbovi and Wilson 2017, 2018). The combined use of metal salt and biopolymer flocculant reveal enhanced removal of orthophosphate $\mathrm{P}_{\mathrm{i}}$, as evidenced by the lower flocculant dosage when used along with metal salts (Table 9.7). The foregoing is consistent with a removal process that follows an electrostatic charge neutralization and an ion-binding adsorption mechanism (cf. Table 2.1; Yang et al. 2016). 

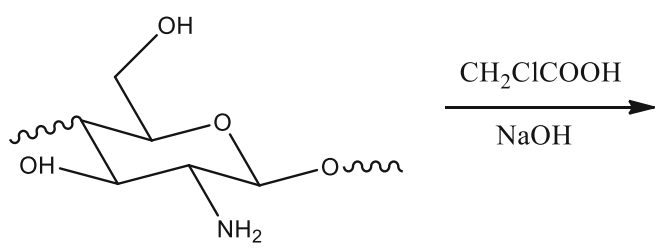

$\mathrm{CMC}$
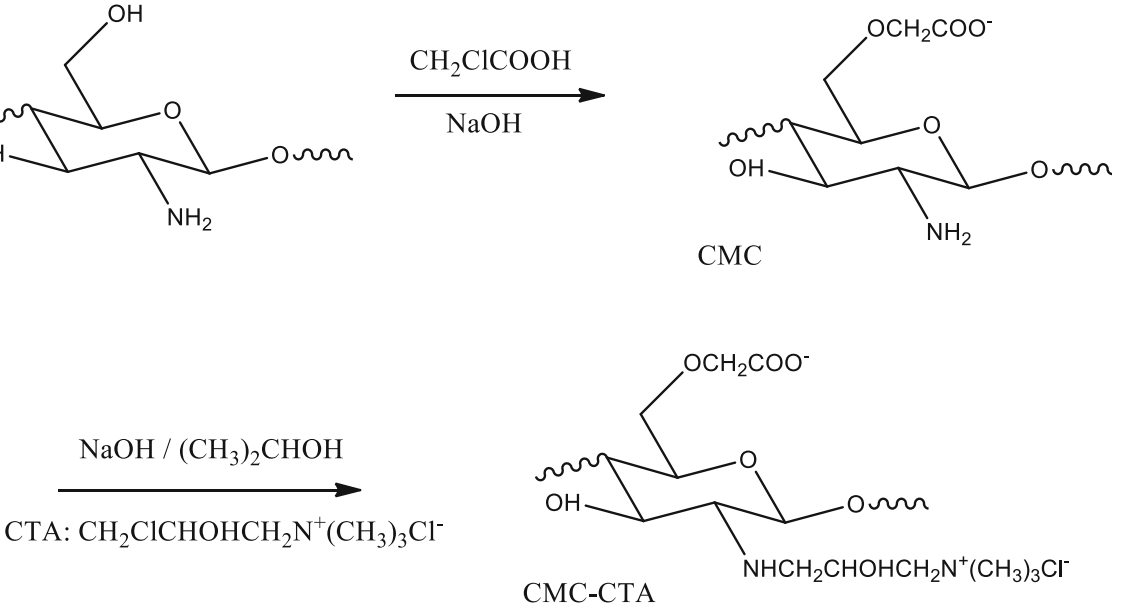

Scheme 9.1 Synthetic route of carboxymethyl-chitosan (CMC) and 3-chloro-2-hydroxypropyl trimethylammonium chloride grafted onto CMC (CTA-CMC). (Adapted from Agbovi and Wilson 2018)

The last few entries of Table 9.7 compare the orthophosphate $\mathrm{P}_{\mathrm{i}}$ removal for carboxymethyl-chitosan, chitosan, and 3-chloro-2-hydroxypropyl trimethylammonium chloride grafted in the absence of added kaolinite (turbidity). The design and chemical structure of these amphoteric biopolymer flocculants is shown in Scheme 9.1.

The removal efficiency for the biopolymer-Fe(III) systems are listed in descending order: 3-chloro-2-hydroxypropyl trimethylammonium chloride grafted onto carboxymethyl-chitosan $>$ chitosan $>$ carboxymethyl-chitosan, in accordance with the trends in the relative zeta-potential of the biopolymers. In the presence of turbidity (400 mg/L kaolinite) and initial orthophosphate $\mathrm{P}_{\mathrm{i}}(25 \mathrm{mg} / \mathrm{L})$, 3-chloro-2hydroxypropyl trimethylammonium chloride grafted onto carboxymethyl-chitosan showed greater orthophosphate $\mathrm{P}_{\mathrm{i}}$ removal versus chitosan and carboxymethylchitosan at all $\mathrm{pH}$ conditions, where optimal turbidity removal $(99.2 \%)$ and orthophosphate $\mathrm{P}_{\mathrm{i}}$ removal $(97.8 \%$ ) was demonstrated at $\mathrm{pH} 4$, according to the experimental results shown in Fig. 9.5.

Based on these selected examples of coagulant-flocculant systems, it can be concluded that enhanced removal of orthophosphate can be achieved through synthetic modification of chitosan, especially in conjunction with Fe(III) coagulants at industrially relevant wastewater conditions. The performance of amphoteric chitosan flocculants can be tuned for optimal performance at variable $\mathrm{pH}$ conditions in response to the type of waterborne contaminant species. Thus, the overview provided herein and elsewhere (Bhalkaran and Wilson 2016) reveals the utility of such biopolymer-flocculants for wider applications aimed at oxoanion removal in water and wastewater treatment. 

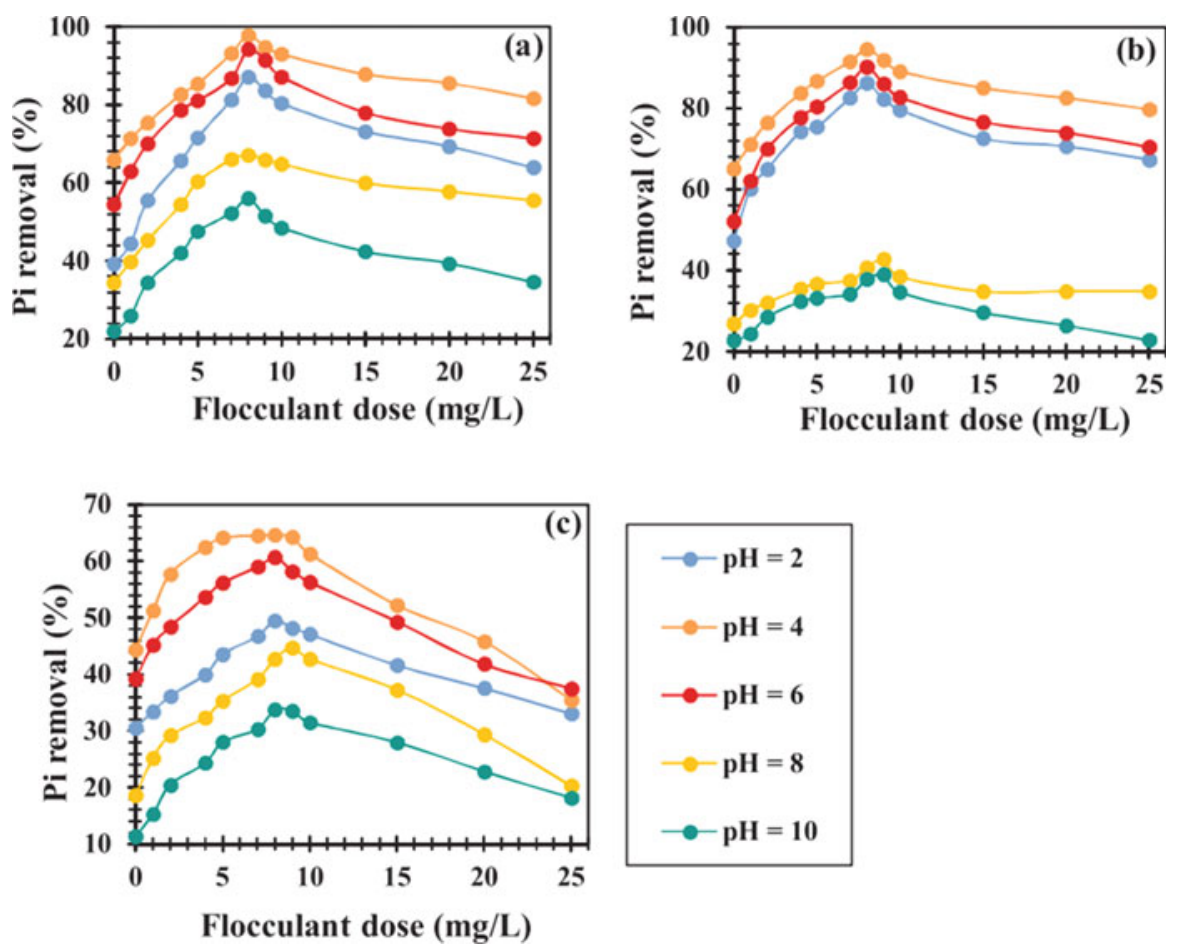

Fig. 9.5 Effect of $\mathrm{pH}$ on the removal of orthophosphate $\mathrm{Pi}$ at variable flocculant dosage; (a) 3-chloro-2-hydroxypropyl trimethylammonium chloride grafted onto carboxymethyl-chitosan (b) chitosan and (c) carboxymethyl-chitosan, where the initial concentration of $P_{i}$ is $25 \mathrm{mg} / \mathrm{L}$. (Reproduced with permission; Agbovi and Wilson 2018)

\subsubsection{Treatment of Cyanobacteria-Laden Source Water}

The proliferation of harmful cyanobacteria in river, lake and reservoir is considered as a serious environmental issue since its ability to produce toxins as well as taste and odor compounds which adversely affect aquatic ecosystems and humans (Schindler et al. 2012). Cyanobacteria will threaten the safety of drinking water when such forms of contaminated water is used for drinking water purposes. Microcystins produced by Microcystis aeruginosa, which is the most notorious species in eutrophic surface waters, are hepatotoxins which pose a health threat on humans. Other algal organic matters could also compromise the safety of drinking water since they are precursors leading to the development of disinfection by-products during chlorination. Generally, most algal organic matters including microcystins are contained within healthy cyanobacteria cells except Cylindrospermopsis raciborskii, which contains around 50\% or less toxin in cells (Newcombe 2009). Its removal in 
dissolved form is more difficult than those in the cells of cyanobacteria. Therefore, an efficient method to remove cyanobacteria cells without damaging the membrane is significant to drinking water treatment.

Coagulation using conventional coagulants is considered as the most important process for algal removal in conventional drinking water treatment due to short detention time and low capital cost. Even though the traditional coagulants, such as polymeric aluminium and ferric chloride, could remove cyanobacteria cells without causing cell lysis (Xu et al. 2016), excess $\mathrm{Al}$ and $\mathrm{Fe}$ will affect the water quality when plenty of traditional coagulant is used to remove cyanobacteria. Furthermore, the traditional coagulant is ineffective at the removal of extracellular microcystins. Recently, increasing demand for environmental-friendly technologies has led to the search for natural, available and efficient materials to be used as coagulants. Chitosan, as a non-toxic and biodegradable coagulant/flocculant, has been extensively applied in water treatment and may be a suitable flocculant for cyanobacteria cells removal in drinking water treatment plants.

For instance, Pei et al. (2014) studied the effects of chitosan on treatment of cyanobacteria-laden source water, where the results showed that chitosan can remove Microcystis aeruginosa cell efficiently without damage the cells. Meanwhile, chitosan can absorb an amount of extracellular microcystins due to the presence of amino and hydroxyl groups in chitosan which give it powerful adsorptive capacity. The impacts of chitosan dosage and flocculation stirring were systematically investigated on Microcystis aeruginosa and microcystins removal. Under optimized conditions, i.e. chitosan concentration: $7.31 \mathrm{mg} / \mathrm{L}$, rapid mix speed: $227 \mathrm{rpm}$, rapid mix time: $2 \mathrm{~min}$, slow mix speed: $19 \mathrm{rpm}$, and slow mix time: 12 min, $99 \%$ of Microcystis aeruginosa cells and $46.5 \%$ microcystins were removed.

Despite there are many desired properties of the chitosan as a coagulant and its relatively low cost, the cost of chitosan is still high compared with the traditional inorganic coagulants used as coagulants in drinking water treatment plants. To address issues of cost, research efforts were directed at finding ways to reduce the dosage of chitosan. Pan et al. (2006) prepared a composite coagulant containing chitosan-modified local soils (chitosan: soil $=1: 10$; weight), where it was found that a loading of $0.025 \mathrm{~g} / \mathrm{L}$ chitosan-modified local soils removed $99 \%$ Microcystis aeruginosa cells (cell intensity: $4.86 \times 10^{9}$ cells/L) within $16 \mathrm{~h}$ for a field enclosure of Taihu Lake. Pei et al. (2016) used a novel hydrogen-terminated porous $\mathrm{Si}$ wafer to enhance Microcystis aeruginosa removal by chitosan at a low dosage. It was found that moderate pre-oxidation by this wafer not only could avoid the damage of Microcystis aeruginosa cell but also can decrease the level of dissolved organic matter, hence, this led to a method for reducing the dosage of chitosan during coagulation.

Another solution to reduce the dosage of chitosan during coagulation is to prepare a coagulant combining the advantages of bioflocculant with inorganic coagulant in water treatment. Ma et al. (2016a, b) studied the effect of a composite coagulant chitosan-aluminum chloride on removal of Microcystis aeruginosa cells in cyanobacteria-laden drinking water for treatment. Results showed that the composite 
coagulant can remove algal cells effectively for stronger entrapment and bridging ability, where negligible cell lysis was observed during the coagulation process. The optimal coagulation performance was obtained when the composite coagulant was set as $2.6 \mathrm{mg} / \mathrm{L}$ chitosan plus $7.5 \mathrm{mg} / \mathrm{L}$ aluminum chloride, under which $97.8 \%$ of intact cells, $53.1 \%$ of extracellular microcystins and almost all extracellular organic matters were simultaneously removed.

Even though the dosage of chitosan was reduced during coagulation as above, its water insolubility (chitosan is soluble in weak acid solution) restricts its application in drinking water treatment processes. Recently, some water-soluble chitosan derivatives have been synthesized. Jin et al. (2017), for example, studied the chitosan quaternary ammonium salt, a water-soluble chitosan derivative, on removal of Microcystis aeruginosa cells during coagulation. It was found that Microcystis aeruginosa cells can be removed efficiently without damage under optimum coagulation conditions: coagulant dosage $1.5 \mathrm{mg} / \mathrm{L}$, rapid mixing for $0.5 \mathrm{~min}$ at $5.04 \mathrm{~g}$ and slow mixing for $30 \mathrm{~min}$ at $0.20 \mathrm{~g}$.

Overall, as shown in Table 9.8, because chitosan and chitosan derivatives are non-toxic and biodegradable, they may be the promising coagulant for treatment of the cyanobacteria-laden source water. However, it is worth to note that their use on cyanobacteria removal is still at the laboratory research phase. The field pilot study on cyanobacteria removal by chitosan or chitosan derivatives should be done to obtain relevant operating parameters in the drinking water treatment plant. It will be helpful in this application to treat the cyanobacteria-containing source water in the drinking water

Table 9.8 Comparison between chitosan and chitosan derivatives on Microcystis aeruginosa cell removal

\begin{tabular}{l|l|l|l|l|l}
\hline Coagulant & $\begin{array}{l}\text { Dose } \\
(\mathrm{mg} / \mathrm{L})\end{array}$ & $\begin{array}{l}\text { Cell } \\
\text { density } \\
(\text { cells/mL) }\end{array}$ & Advantage(s) & Problem(s) & References \\
\hline Chitosan & 7.31 & $2 \times 10^{6}$ & Degradability & $\begin{array}{l}\text { Water } \\
\text { insolubility }\end{array}$ & $\begin{array}{l}\text { Pei et al. } \\
(2014)\end{array}$ \\
\hline $\begin{array}{l}\text { Chitosan-modified } \\
\text { local soils } \\
\text { (chitosan: } \\
\text { soil }=1: 10 ; \\
\text { weight })\end{array}$ & $\begin{array}{l}25 \\
\text { (chitosan } \\
\text { dose: } \\
2.27)\end{array}$ & $4.86 \times 10^{6}$ & $\begin{array}{l}\text { Degradability; } \\
\text { low dosage of } \\
\text { chitosan }\end{array}$ & $\begin{array}{l}\text { Water insolubil- } \\
\text { ity of chitosan }\end{array}$ & $\begin{array}{l}\text { Pan et al. } \\
(2006)\end{array}$ \\
\hline $\begin{array}{l}\text { H-PSi wafer } \\
\text { preoxide plus } \\
\text { chitosan }\end{array}$ & 0.75 & $2 \times 10^{6}$ & $\begin{array}{l}\text { Degradability; } \\
\text { low dosage of } \\
\text { chitosan }\end{array}$ & $\begin{array}{l}\text { High cost of } \\
\text { H-PSi wafer; } \\
\text { water insolubil- } \\
\text { ity of chitosan }\end{array}$ & $\begin{array}{l}\text { Pei et al. } \\
(2016)\end{array}$ \\
\hline $\begin{array}{l}\text { CTSAC (chitosan: } \\
\text { aluminum chlo- } \\
\text { ride }=1: 3 ; \text { weight) }\end{array}$ & $\begin{array}{l}10.1 \\
(\text { chitosan } \\
\text { dose:2.6) }\end{array}$ & $2 \times 10^{6}$ & $\begin{array}{l}\text { Degradability; } \\
\text { low dosage of } \\
\text { chitosan }\end{array}$ & $\begin{array}{l}\text { Water insolubil- } \\
\text { ity of chitosan }\end{array}$ & $\begin{array}{l}\text { Ma et al. } \\
(2016 a, b)\end{array}$ \\
\hline HTCC & 1.5 & $1 \times 10^{6}$ & $\begin{array}{l}\text { Degradability; } \\
\text { water } \\
\text { solubility }\end{array}$ & High cost & $\begin{array}{l}\text { Jin et al. } \\
(2017)\end{array}$ \\
\hline
\end{tabular}

$H$-PSi hydrogen-terminated porous $\mathrm{Si}, C T S A C$ chitosan-aluminum chloride, $H T C C$ chitosan quaternary ammonium salt 
treatment plant. In addition, cheaper and better performance chitosan derivatives should be developed in the future. This also contributes to the wide range of applications of chitosan derivatives in drinking water treatment plant.

\subsubsection{Sludge Dewatering}

One of the major environmental problems facing wastewater treatment is the high volume of sludge produced by sewage treatment. Sludge treatment or dewatering, disposal and management are major challenges in the water industries, in particular to reduce the costs of final disposal including transportation. Typically, dewatering is focused on reducing the weight and volume of the sludge. For this, the primary means of volume reduction (before sludge waste) is water removal. Depending on the operation and process used, sludge can be very dilute suspension which generally contain a heterogeneous mixture of $50-80 \%$ of pollution in form of a high-organic load, colloids, pathogenic germs, mineral particles, captions and metals (Zhai et al. 2012). That is why, if they are inadequately managed, they can pose a serious environmental consequence. Hence, the main target of sludge treatment is (i) to dewatering as high a solids level as possible (in the most economical manner), (ii) to eliminate smell by reducing the quantity of the organic solids, and (iii) to reduce number of disease-causing microorganisms present in the solids. All these treatments are important for both economical and environmental reasons.

Sludge dewatering separates sludge into liquid and solid components for waste minimization. This requires an efficient conditioning step and there are various technologies involving biological, chemical and/or physical treatments. It is important to point out that, after treatment, both the liquid and solid components may contain contaminants. Indeed, the dewatering step is not intended to treat the liquid of sludge. Generally, chemical methods are used to enhance sludge filtration and final dewatering efficiency. They consists in the addition of chemicals, e.g. acids, alkalis, surfactants, coagulants and/or flocculants, to the sludge to change its nature and to improve dewatering performance. Coagulation/flocculation is one of the most commonly used sludge conditioning approaches when cost and efficiency are considered (Wei et al. 2018). In this treatment, colloidal particles present in the sludge form large flocs and compacted cakes for the improvement of sedimentation and dewatering performance by increasing the sludge dewatering rates and solid content (Qi et al. 2011; Suopajärvi et al. 2003; Wei et al. 2018). The additives used can be classified into two main groups: mineral additives such as metal salts and organic polymer (synthetic products or natural polymers). The synthetic ones may be cationic, anionic or non-ionic. In most cases, they are derived from oil-based and non-renewable raw materials (Suopajärvi et al. 2003). Some of these products often lead to secondary pollution and new environmental problems (Renault et al. 2009a). So, the sludge formed has a limited potential for recycling due to its non-biodegradability (Zahrim et al. 2011). Natural 
polymers, such as starches, celluloses and chitosan, and microbial materials, such as bacteria, fungi and yeast, can reduce such environmental problems, reuse sludge as fertilizer with environment respect and encourage sludge proper handling and disposal (Bolto and Gregory 2007).

Depending on the nature of the solids to be treated, chemical conditioning can reduce the $90-99 \%$ incoming moisture content to $65-85 \%$ (Yu et al. 2008). Moisture content in sludge directly corresponds to the dewatering extent. Other parameters can be also used such as the capillary suction time (in s) and specific resistance in filtration (in $\mathrm{m} / \mathrm{kg}$ ) (Christensen et al. 1985; Ripperger et al. 2012). These parameters are popular in evaluating sludge dewaterability. In a capillary suction time test, a filtration force generated by the capillary action of an absorbent filter paper is applied to the sample. The lower the capillary suction time the higher the dewatering rate, i.e. the better sludge filtration properties. This test is simple, rapid and inexpensive because it does not require an external source of pressure or suction. The specific resistance in filtration test requires the application to be in a vacuum. It is important to note that the capillary suction time and specific resistance in filtration parameters are empirical and lacking in accuracy. However, they rapidly provide an indication of a sample filtration capability which is usually sufficient for operational controls.

Figures 9.6, 9.7, 9.8 and 9.9 show a typical example of obtained results. The raw sludge originates from a municipal waste water treatment plant (Beni-Messous, $15 \mathrm{~km}$ west of Algiers, Algeria). Its characteristics are described in Table 9.9. The following conditions were used: sludge conditioning was carried out by flocculation using a conventional Jar Test with six ramps; samples of $100 \mathrm{~mL}$ in a $500 \mathrm{~mL}$ beaker were mixed with solutions containing different amounts of conditioners calculated on the basis of chemical mass per unit mass of dry solids contents of the sludge

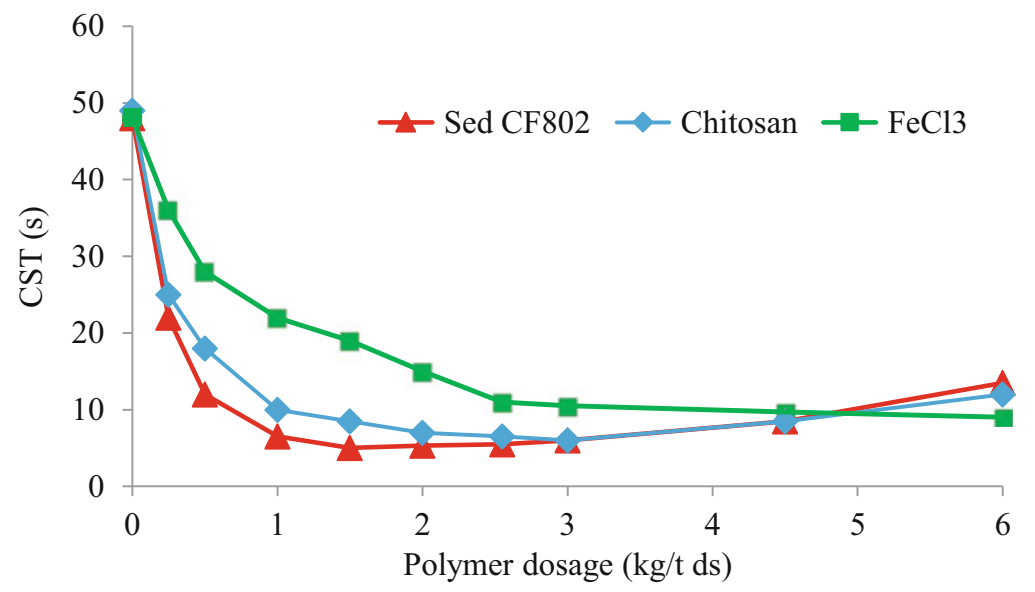

Fig. 9.6 Capillary suction time (CST) versus flocculant dosage. Flocculants: commercial cationic polymer Sedipur CF802 abbreviated Sed CF802, chitosan and ferric chloride $\mathrm{FeCl}_{3}$; the capillary suction time parameter was evaluated according to the Standard Method 2710G (APHA, AWWA and WEF 1995) with a portable apparatus (Triton 304B, chromatography paper Whatman ${ }^{\circ} 17$ ) 


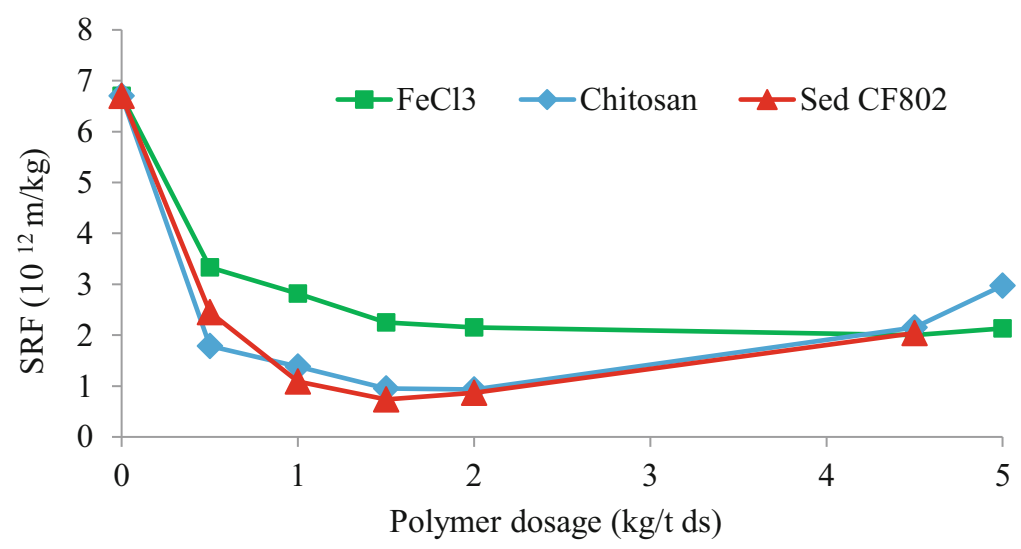

Fig. 9.7 Specific resistance to filtration (SRF) versus flocculant dosage. Flocculants: ferric chloride $\mathrm{FeCl}_{3}$, chitosan and a commercial cationic polymer Sedipur CF802 abbreviated Sed CF802

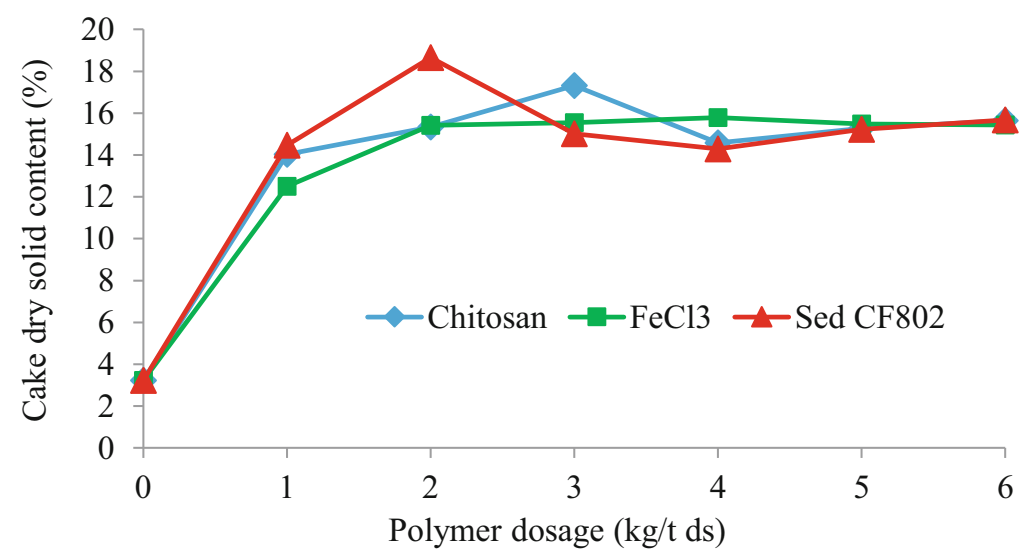

Fig. 9.8 Cake dry solid content vs. flocculant dosage. Flocculants: chitosan, ferric chloride $\mathrm{FeCl}_{3}$ and a commercial cationic polymer Sedipur CF802 abbreviated Sed CF802

(expressed in kilogram per ton of dry solids); the jar test was operated at $140 \mathrm{rpm}$ for $20 \mathrm{~s}$ for intense mixing of the polyelectrolyte into the sludge, and then stirring speed was reduced to $28 \mathrm{rpm}$ for $2 \mathrm{~min}$ to promote floc growth. Dewatering sludge was processed using laboratory-scale pressure filtration cell standardized (APHA, AWWA and WEF 1995). After flocculation, conditioned sludge is immediately transferred into the filtration cell. An appropriate pressure $\left(10 \mathrm{~kg} / \mathrm{cm}^{2}\right)$ was applied. During the introduction of the piston, a certain amount of filtrate can flow under the effect of gravity without pressing. The filtration time was set to 1 hour. Collected filtrates were measured as function of time. Dry solids content (ds in \%) of the recuperated cake and filtrate turbidity were determined according to procedures 


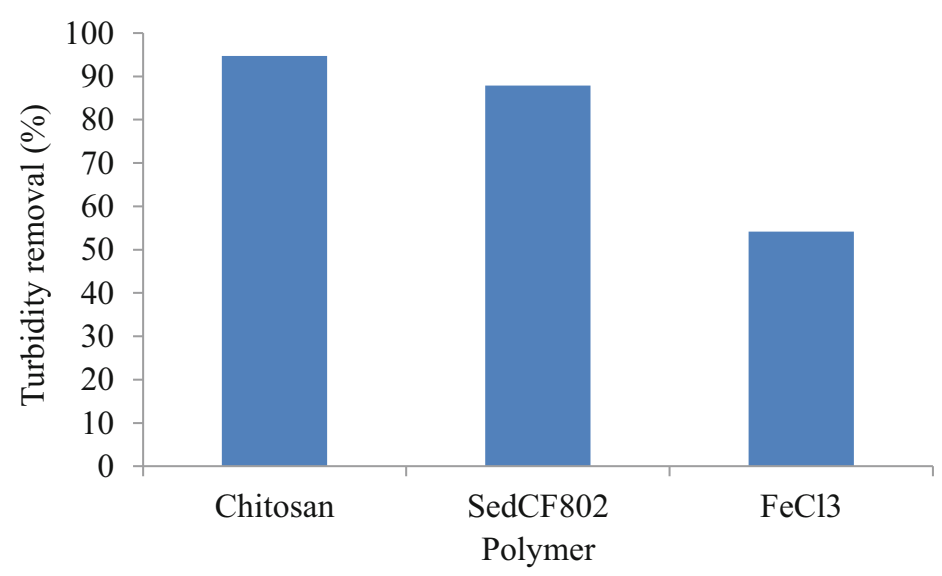

Fig. 9.9 Turbidity removal versus flocculant dosage. Flocculants: chitosan ferric, a commercial cationic polymer Sedipur CF802 abbreviated Sed CF802 and chloride $\mathrm{FeCl}_{3}$

Table 9.9 Characteristics of raw sludge before conditioning

\begin{tabular}{l|l|c}
\hline Parameter & Unit & Value \\
\hline $\mathrm{pH}$ & & 8.3 \\
\hline Total suspended solids & $\mathrm{g} / \mathrm{L}$ & 3.3 \\
\hline Volatile suspended solids & $\mathrm{g} / \mathrm{L}$ & 17 \\
\hline Dry solid content & $\%$ & 3.22 \\
\hline Capillary suction time & $\mathrm{s}$ & 48 \\
\hline Specific resistance to filtration & $10^{12} \mathrm{~m} / \mathrm{kg}$ & 6.78 \\
\hline Temperature & ${ }^{\circ} \mathrm{C}$ & 25
\end{tabular}

given in Standard Methods (APHA, AWWA and WEF 1995). Chitosan efficiency was compared to synthetic cationic polymer Sedipur CF802 abbreviated Sed CF802, and ferric chloride $\mathrm{FeCl}_{3}$.

The capillary suction time is an empirical measure of the resistance offered by the sludge to the withdrawal of water. In Fig. 9.6, the results show that the capillary suction time value has been reduced from $48 \mathrm{~s}$ obtained in the raw sludge case to $5 \mathrm{~s}$ and $6 \mathrm{~s}$ with optimal dosage, in the range of $2-3$ and $1.5-3 \mathrm{~kg} / \mathrm{t} \mathrm{ds}$ of Sed CF802 and chitosan, respectively. Beyond the optimal dosage, the capillary suction time value increases again. Otherwise, with sludge conditioned with $6 \mathrm{~kg} / \mathrm{t} \mathrm{ds}$ as optimal dose of $\mathrm{FeCl}_{3}$, capillary suction time value was around $9 \mathrm{~s}$. Indeed, the two cationic polyelectrolytes showed a good dewaterability. The low capillary suction time obtained using cationic polyelectrolytes is due to smaller flocs and sludge containing less bound water. The sludges are therefore dewatered faster than those obtained with $\mathrm{FeCl}_{3}$. However, further increase in polyelectrolyte concentration increased the capillary suction time. This is associated with the overdosing phenomena caused by excess polyelectrolyte remaining in the liquid phase leading to the viscosity increase and then deteriorating the sludge dewaterability. Otherwise, saturation of 
the colloidal surface with polymer is usually accompanied by a reversal of the surface charge. The optimal polymer dosage is commonly associated with partial coverage of the colloidal surface, accompanied by a minimum surface charge (Lee and Liu 2000).

Figure 9.7 depicts the evolution of specific resistance in filtration data as a function of dosage of each flocculant. Initially, the specific resistance in filtration value of unconditioned sludge was $6.78 \times 10^{12} \mathrm{~m} / \mathrm{kg}$. The value is decreased when both cationic polyelectrolytes and $\mathrm{FeCl}_{3}$ were added. The optimum doses for Sed CF802 and chitosan were about $1.5-2 \mathrm{~kg} / \mathrm{t}$ ds for both polyelectrolytes. Beyond the optimum value, the SRF increased again. SRF values of sludge conditioned with Sed CF802 and chitosan at the respective optimum doses were $0.634 \times 10^{12} \mathrm{~m} / \mathrm{kg}$ and $0.932 \times 10^{12} \mathrm{~m} / \mathrm{kg}$, respectively. On the other hand, $4.5 \mathrm{~kg} / \mathrm{t}$ ds of $\mathrm{FeCl}_{3}$ has reduced specific resistance in filtration to $2 \times 10^{12} \mathrm{~m} / \mathrm{kg}$. Through these results, the objective of this study was accomplished; adding flocculating agents improved the dewaterability of sludge, i.e. reduced the specific resistance in filtration. Chitosan as well as Sed CF802 and $\mathrm{FeCl}_{3}$ helped to increase the sludge particle size by agglomerating the small fines of the sludge colloids (causing blinding) and to form large flocs (which are easily separated from the water). This flocs agglomeration is translated by the specific resistance in filtration decrease and consequently the filterability improvement.

The evolution of the cake dryness according to the dose of each flocculant is presented in Fig. 9.8. A significant increase in dryness to $17.31 \%$ with $3 \mathrm{~kg} / \mathrm{t}$ ds of chitosan has been recorded and $2 \mathrm{~kg} / \mathrm{t}$ ds of Sed CF802 increased cake dryness to $18.65 \%$. The cakes formed with application of both polyelectrolytes were uniform, with thicknesses of $0.5 \mathrm{~cm}$. These results led to the conclusion that the performance of these two polymers was substantially similar, with a slight difference. Otherwise, $15.78 \%$ of cake dryness was obtained using $4 \mathrm{~kg} / \mathrm{t}$ ds of $\mathrm{FeCl}_{3}$. Obtaining large flocs after flocculation was conducive to good settle ability and filterability. However, the filterability did not depend on the size of the flocs. It essentially depended on floc cohesion or their mechanical and bond strengths uniting the elementary particles that make up the formed cluster. The weakness of these links may result in a change in the structure of the filter cake which becomes less porous, and consequently a decrease in the rate of filtration.

Figure 9.9 depicts the filtrate turbidity after filtration tests of flocculated sludges with different polymers. It shows that both chitosan and SedCF802 with $94.68 \%$ and $87.85 \%$ respectively, a maximum filtrate cleaning (minimum nephelometric turbidity unit, NTU, values) have been achieved. By cans, $54.18 \%$ of turbidity abatement has been obtained using $\mathrm{FeCl}_{3}$. A better capture efficiency of some fine dispersed particles in the aqueous phase translates the lower residual turbidity of filtrate when both cationic polyelectrolytes were used. These fine, dispersed particles of sludge were flocculated to form primary flocs due to electrostatic attraction. Lee and Liu (2000) have shown that knowing that the fine particles should cause a decrease in cake porosity, flocculation of sludge particles by the cationic polyelectrolyte could prevent fine particles from clogging up the filter. This also contributes to the enhanced dewaterability of sludge. 
The sludge particles are most frequently known to be positively or negatively charged. Chemical conditioners, often with opposite charges, are used to coagulate or flocculate sludge colloids by charge neutralization, leading to the establishment of interactions between charged particles. It is well known that the two main mechanisms of flocculation using organic polymers are the destabilization of the colloidal system by charge neutralization and the bridging intra-particles. Polymer can adsorb on the surface of a colloidal particle due to a chemical strength (chemical bonding) or physical force (e.g. van der Waals forces), or both. Some parts of the polymer chains can then be determined by bare paths on another particle and therefore closest to form bridges. So, destabilization of sludge is interpreted as a neutralization charge and/or particles bridging during the application of polyelectrolytes. The combined action of the mass and charge of the polymer helps to implement both phenomena bridging and charge neutralization (Gregory and Barany 2011). The bridge allows the polymer to set a large number of particles and to include them in large flocks. Since chitosan is a cationic polyelectrolyte, in our case, the clotting mechanism is essentially borne by a double effect: charge neutralization and bridging flocs. Chitosan is adsorbed on the surface of the colloidal particles by attractive electrostatic interactions between the negative charges of the surface of the colloidal particles and the amine groups of the chitosan (Renault et al. 2009a, b). These also promote adsorption (Gregory and Barany 2011) and this explain the fact that the adsorbed amount of chitosan increases with the increase of the dose of added chitosan.

According to results related to the effect of the chitosan dose, the general trend showed that each increase of chitosan above its optimum concentration increased specific resistance in filtration and decreased cake dry solid contents. One hypothesis for this phenomenon would be the reversal of load and re-stabilization of colloidal particles which have been coagulated. This re-stabilization of loads depends on the zeta potential of the solution (Gregory and Barany 2011). In fact, chitosan, by its constitution, has a surplus of electrical charges and is solvated by water trapping colloidal particles causing turbidity. Indeed, these authors have reported that the excessive addition of polymer creates hyperconductive water where collisions between particles due to electric forces are so intense; they disrupt completely the balance of the solution (Gregory and Barany 2011).

In conclusion, compared to a commercial synthetic polymer, chitosan has shown the same efficiency in terms of sludge conditioning. Chitosan, as a natural organic flocculant, may be a promising substitute for conventional flocculants used so far in the field of sludge conditioning. Its sole inconvenience is its relatively high cost, which could be minimized by future technological developments.

\subsubsection{Post-Treatment of Sanitary Landfill Leachate}

The landfill leachate presents high concentrations of ammonia nitrogen, organic matter biodegradable, recalcitrant compounds, such as humic substances, heavy metals and xenobiotic organic compounds (Kjeldsen et al. 2002). Biological 
treatment, is commonly used to remove the bulk of organic matter biodegradable and ammonia nitrogen, due to its reliability, simplicity and high cost-effectiveness. As a complementary alternative to the biological treatment, the coagulation-flocculation process has been employed to reduce the concentration of recalcitrant organic matter and toxicity present in the landfill leachate (Renou et al. 2008; Ziyang et al. 2009). Nevertheless, chemical coagulants may have adverse effects on the environment. Hence, it is suggested that chitosan could be a better alternative (Verma et al. 2012; Ramli and Aziz 2015; Nascimento et al. 2016).

Nascimento et al. (2016) carried out a determination of the optimum dosage and $\mathrm{pH}$ values for coagulation-flocculation of biologically-treated leachate using chitosan as biocoagulant for the removal of recalcitrant organic matter. The performance of chitosan was compared to aluminum sulfate which is a metal coagulant widely used in wastewater treatment plants. The coagulant dosage investigated ranged from 700 to $1100 \mathrm{mg} / \mathrm{L}$ for chitosan and from 1300 to $1700 \mathrm{mg} / \mathrm{L}$ for alum; the $\mathrm{pH}$ value was varied from 6.0 to 9.0 for chitosan and from 8.0 to 10.0 for alum. The gradient for rapid mixing, time for rapid mixing, gradient for flocculation mixing, and flocculation time were held constant. Their values for chitosan and alum were: $400 \mathrm{~s}^{-1}$ and $869 \mathrm{~s}^{-1}$ (gradient for rapid mixing), $30 \mathrm{~s}$ and $10 \mathrm{~s}$ (time for rapid mixing), $30 \mathrm{~s}^{-1}$ and $30 \mathrm{~s}^{-1}$ (gradient for flocculation), and $10 \mathrm{~min}$ and $10 \mathrm{~min}$ (flocculation time), respectively.

Based on a mathematical model and graphical optimization, the results showed that chitosan dosages below $700 \mathrm{mg} / \mathrm{L}$ and $\mathrm{pH}$ values between 6.0 and 6.5 or chitosan dosage near $900 \mathrm{mg} / \mathrm{L}$ and $\mathrm{pH}$ values between 8.0 and 8.5 lead to greater removal efficiencies of recalcitrant organic matter (50-80\%) and the highest turbidity removal $(90 \%)$ was obtained at a lower dosage, less than $900 \mathrm{mg} / \mathrm{L}$, with a $\mathrm{pH}$ between 6.5 and 9.5; and an alum dosage between 1542 and $1762 \mathrm{mg} / \mathrm{L}$ with a $\mathrm{pH}$ between 8.5 and 10.0 lead to greater removal efficiency values. Employing the Response Optimizer function (Minitab ${ }^{\circledR} 16$ software), the maximum efficiency removal of true color (80\%) and the turbidity removal (91\%) were found using $960 \mathrm{mg} / \mathrm{L}$ of chitosan at $\mathrm{pH} 8.5$; and using $1610 \mathrm{mg} / \mathrm{L}$ of alum at $\mathrm{pH} 9.5$, the true color removal efficiency was $87 \%$ and the turbidity removal reached $81 \%$ (Nascimento et al. 2016).

The authors explained that with decreasing solution $\mathrm{pH}$, part of the humic substances in the leachate became insoluble, resulting in a reduced level of remaining organic matter. Consequently, the dosage of chitosan required for the destabilization of the colloidal system is less and lower $\mathrm{pH}$ (acidic) conditions. Moreover, at a pH of 6.0 or less, more than $90 \%$ of the amine groups are protonated. Thus, the lower dosage of chitosan required for efficient coagulation-flocculation at lower $\mathrm{pH}$. This can be explained by the acid-base properties of chitosan and the degree of dissociation of the polyelectrolyte (Guibal and Roussy 2007). The $\mathrm{pK}_{\mathrm{a}}$ of the amine groups is close to 6.3-6.4 for fully dissociated chitosan (with a deacetylation degree of close to $90 \%$ ). The authors concluded that the high sensitivity of the performance of chitosan in removing true color and turbidity levels opens up possibilities for its use as a coagulant to aid in the removal of recalcitrant contaminants in landfill leachate. 


\subsection{Conclusion}

Chitosan, a partially deacetylated polysaccharide obtained from chitin, has received considerable attention in recent years as a versatile bioflocculant. Its potential application as an efficient and eco-friendly material for environmental purposes has been well investigated. As reported in this chapter, chitosan can be used for water and wastewater treatment, sludge dewatering and post-treatment of sanitary landfill leachate. In general, the data published have shown comparable or better flocculation efficiency compared to the current commercial ones, and thus chitosan has strong potential in the near future. However, although its performance was satisfactory and pilot plants were designed, the economic feasibility to design large scale treatment plants still need to be carried out. Moreover, attention should be given towards investigating the intrinsic characteristics of the biopolymer, i.e. degree of deacetylation and molecular weight, and the various operating parameters, e.g. dosage, initial $\mathrm{pH}$, settling time, etc., which could significantly affect the viability and effectiveness of chitosan and its derivatives. In addition, more research is still needed to understand the mechanisms of flocculation in order to control flocs density and removal ability of pollutants.

\section{References}

Abebe LS, Chen XY, Sobsey MD (2016) Chitosan coagulation to improve microbial and turbidity removal by ceramic water filtration for household drinking water treatment. Int J Environ Res Public Health 13:3. https://doi.org/10.3390/ijerph13030269

Adnan O, Abidin ZZ, Idris A, Kamarudin S, Al-Qubaisi MS (2017) A novel biocoagulant agent from mushroom chitosan as water and wastewater therapy. Environ Sci Pollut Res 24:20104-20112. https://doi.org/10.1007/s11356-017-9560-x

Agbovi HK, Wilson LD (2017) Flocculation optimization of orthophosphate with $\mathrm{FeCl}_{3}$ and alginate using the Box-Behnken response surface methodology. Ind Eng Chem Res 56:3145-3155. https://doi.org/10.1021/acs.iecr.6b04765

Agbovi HK, Wilson LD (2018) Design of amphoteric chitosan flocculants for phosphate and turbidity removal in wastewater. Carbohydr Polym 189:360-370. https://doi.org/10.1016/j. carbpol.2018.02.024

Agbovi HK, Wilson LD, Tabil LG (2017) Biopolymer flocculants and oat hull biomass to aid the removal of orthophosphate in wastewater treatment. Ind Eng Chem Res 56:37-46. https://doi. org/10.1021/acs.iecr.6b04092

Ahmad AL, Sumathi S, Hameed BH (2005a) Adsorption of residue oil from palm oil mill effluent using powder and flake chitosan: equilibrium and kinetic studies. Water Res 39:2483-2494. https://doi.org/10.1016/j.watres.2005.03.035

Ahmad AL, Sumathi S, Hameed BH (2005b) Residual oil and suspended solid removal using natural adsorbents chitosan, bentonite and activated carbon: a comparative study. Chem Eng J 108:179-185. https://doi.org/10.1016/j.cej.2005.01.016

Ahmad AL, Sumathi S, Hameed BH (2006) Coagulation of residue oil and suspended solid in palm oil mill effluent by chitosan, alum and PAC. Chem Eng J 118:99-105. https://doi.org/10.1016/j. cej.2006.02.001 
Altaher H (2012) The use of chitosan as a coagulant in the pre-treatment of turbid sea water. J Hazard Mater 233-234:97-102. https://doi.org/10.1016/j.jhazmat.2012.06.061

Ang WL, Mohammad AW, Benamor A, Hilal N (2016) Chitosan as natural coagulant in hybrid coagulation-nanofiltration membrane process for water treatment. J Environ Chem Eng 4:4857-4862. https://doi.org/10.1016/j.jece.2016.03.029

APHA, AWWA, WEF (1995) Standard methods for the examination of water and wastewater, 19th edn. American Public Health Association, American Water Works Association, Water Environment Federation, Washington, DC, pp 2-54

Arfin T (2017) Chapter 5: Chitosan and its derivatives: overview of commercial applications in diverse fields. In: Ahmed S, Ikram S (eds) Chitosan - derivatives, composites and applications. Scrivener Publishing LLC/Wiley, Beverly/Hoboken, pp 115-150. https://doi.org/10.1002/ 9781119364849.ch5

Arias-Lizarraga MD, Mendez-Gomez E (2014) Removal of solids from wastewater from the fishmeal industry. Tecnologia Y Ciencias Del Agua 5:115-123

Azarova YA, Pestov AV, Bratskaya SZ (2016) Application of chitosan and its derivatives for solidphase extraction of metal and metalloid ions: a mini-review. Cellulose 23:2273-2289. https:// doi.org/10.1007/s10570-016-0962-6

Bala JD, Lalung J, Ismail N (2015) Studies on the reduction of organic load from palm oil mill effluent (POME) by bacterial strains. Int J Recycl Org Waste Agric 4:1-10. https://doi.org/10. 1007/s40093-014-0079-6

Banu RJ, Do KU, Yeom IT (2007) Phosphorus removal in low alkalinity secondary effluent using alum. Int J Environ Sci Technol 5:93-98. https://doi.org/10.1007/BF03326001

Barbusinski K, Salwiczek S, Paszewska A (2016) The use of chitosan for removing selected pollutants from water and wastewater - short review. Architect Civil Eng Environ 9:107-115

Bello MM, Raman AAA (2017) Trend and current practices of palm oil mill effluent polishing: application of advanced oxidation processes and their future perspectives. J Environ Manag 198:170-182. https://doi.org/10.1016/j.jenvman.2017.04.050

Bello MM, Nourouzi MM, Abdullah LC, Choong TS, Keshani S (2013) POME is treated for removal of color from biologically treated POME in fixed bed column: applying wavelet neural network (WNN). J Hazard Mater 262:106-113. https://doi.org/10.1016/j.jhazmat.2013.06.053

Besse V, Illy N, David G, Caillol S, Boutevin B (2016) A chitosan derivative containing both carboxylic acid and quaternary ammonium moieties for the synthesis of cyclic carbonates. ChemSusChem 9:2167-2173. https://doi.org/10.1002/cssc.201600499

Bhalkaran S, Wilson LD (2016) Investigation of self-assembly processes for chitosan-based coagulant-flocculant systems: a mini-review. Int J Mol Sci 17:1662. https://doi.org/10.3390/ ijms 17101662

Blockx J, Verfaillie A, Thielemans W, Muylaert K (2018) Unravelling the mechanism of chitosandriven flocculation of microalgae in seawater as a function of pH. ACS Sustain Chem Eng 6:11273-11279. https://doi.org/10.1021/acssuschemeng.7b04802

Bolto B, Gregory J (2007) Organic polyelectrolytes in water treatment. Water Res 41:2301-2324. https://doi.org/10.1016/j.watres.2007.03.012

Bonecco MB, Martínez Sáenz MG, Buffa LM (2017) Chapter 4: Chitosan, from residue to industry. In: Masuell M, Renard D (eds) Advances in physicochemical properties of biopolymers. Bentham e-Books, Bentham Science Publishers, Sharjah, pp 224-256. ISBN: 978-1-68108545-6

Bratby J (1980) Coagulation and flocculation. Uplands Press Ltd., Croydon, $354 \mathrm{p}$

Bratby J (2006) Coagulation and flocculation in water and wastewater treatment, 2nd edn. IWA Publishing, London, 450 p. ISBN: 1843391066

Chan YJ, Chong MF, Law CL (2011) Optimization on thermophilic aerobic treatment of anaerobically digested palm oil mill effluent (POME). Biochem Eng J 55:193-198. https://doi.org/10. 1016/j.bej.2011.04.007

Chen J, Luan Z (2010) Enhancing phosphate removal by coagulation using polyelectrolytes and red mud. Fresenius Environ Bull 19:2200-2204. https://doi.org/10.1016/S0304-3894(03)00070-0 
Chen CY, Wu CY, Chung YC (2015) The coagulation characteristics of humic acid by using acidsoluble chitosan, water-soluble chitosan, and chitosan coagulant mixtures. Environ Technol 36:1141-1146. https://doi.org/10.1080/09593330.2014.982719

Chong MF (2012) Chapter 8: Direct flocculation process for wastewater treatment. In: Sharma SK, Sanghi R (eds) Advances in water treatment and pollution prevention. Springer, Dordrecht, pp 201-230. ISBN: 978-94-007-4203-1

Christensen J, Sørensen P, Christensen G, Hansen J (1985) Mechanisms for overdosing in sludge conditioning. J Environ Eng 119:159-171

Cox M, Négré P, Yurramendi L (2007) Industrial liquid effluents. INASMET Tecnalia, San Sebastian, p 283. ISBN: 84-95520-14-1

Crini G (2015) Non-conventional adsorbents for dye removal. In: Sharma SK (ed) Green chemistry for dyes removal from wastewater. Scrivener Publishing LLC, Beverly, pp 359-407. ISBN: 978-1-118-72099-8

Crini G, Badot PM (2007) Traitement et épuration des eaux industrielles polluées. PUFC Press, Besançon, 352 p. ISBN: 2848671971

Crini G, Badot PM (2008) Application of chitosan, a natural aminopolysaccharide, for dye removal from aqueous solutions by adsorption processes using batch studies: a review of recent literature. Prog Polym Sci 33:399-447. https://doi.org/10.1016/j.progpolymsci.2007.11.001

Crini G, Badot PM, Morin-Crini N (2009a) Traitement des eaux par du chitosane: intérêts, méthodes et perspectives. Tech Ing RE-126:1-13

Crini G, Badot PM, Guibal E (eds) (2009b) Chitine et chitosane - du biopolymère à l'application. PUFC Press, Besançon, 303 p. ISBN: 978-2-84867-249-6

Crini G, Morin-Crini N, Fatin-Rouge N, Déon S, Fievet P (2017) Metal removal from aqueous media by polymer-assisted ultrafiltration with chitosan. Arab J Chem 10:S3826-S3839. https:// doi.org/10.1016/j.arabjc.2014.05.020

de Alvarenga ES (2011) Chapter 5: Characterization and properties of chitosan. In: Elnashar M (ed) Biotechnology of biopolymers. InTech, Rijeka, pp 91-108. https://doi.org/10.5772/17020

de Andrade JR, Oliveira MF, da Silva MGC, Vieira MGA (2018) Adsorption of pharmaceuticals from water and wastewater using nonconventional low-cost materials: a review. Ind Eng Chem Res 57:3103-3127. https://doi.org/10.1021/acs.iecr.7b05137

de Oliveira TV, Cardoso SL, Vieira RB, Vieira PA, Cardoso VL (2016) Biodegradation of effluent contaminated with diesel oil and gasoline using chitosan as a natural coagulant in a continuous process. Braz J Chem Eng 33:863-869. https://doi.org/10.1590/0104-6632. 20160334s20150193

Desbrières J, Guibal E (2018) Chitosan for wastewater treatment. Polym Int 67:7-14. https://doi. org/10.1002/pi.5464

Dima JB, Sequeiros C, Zaritzky N (2017) Chapter 3:Chitosan from marine crustaceans: production, characterization and applications. In: Shalaby EA (ed) Biological activities and application of marine polysaccharides. InTech, Rijeka, pp 39-56. https://doi.org/10.5772/65258

Ding GT, Yaakob Z, Takriff MS, Salihon J, Rahaman MSA (2016) Biomass production and nutrients removal by a newly-isolated microalgal strain Chlamydomonas $s p$ in palm oil mill effluent (POME). Int J Hydrog Energy 41:4888-4895. https://doi.org/10.1016/j.ijhydene.2015. 12.010

Domard A, Domard M (2001) Chitosan: structure-properties relationship and biomedical applications. In: Severian D (ed) Polymeric biomaterials. Marcel Dekker, New York, pp 187-212

Dong C, Chen W, Liu C (2014) Flocculation of algal cells by amphoteric chitosan-based flocculant. Bioresour Technol 170:239-247. https://doi.org/10.1016/j.biortech.2014.07.108

Dunets CS, Zheng Y (2015) Combined precipitation/flocculation method for nutrient recovery from greenhouse wastewater. Hortscience 50:921-926. http://hortsci.ashspublications.org/content/ 50/6/921.full.pdf+html

Dutta PK, Dutta J, Tripathi VS (2004) Chitin and chitosan: chemistry, properties and applications. J Sci Ind Res 63:20-31 
El Halah A, López-Carrasquero F, Contreras J (2018) Applications of hydrogels in the adsorption of metallic ions. Revista Ciencia Ingenieria 39:57-70

Ferhat M, Kadouche S, Drouiche N, Messaoudi K, Lounici H (2016) Competitive adsorption of toxic metals on bentonite and use of chitosan as flocculant coagulant to speed up the settling of generated clay suspensions. Chemosphere 165:87-93. https://doi.org/10.1016/j.chemosphere. 2016.08.125

Fierro S, Del Pilar Sánchez-Saavedra M, Copalcúa C (2008) Nitrate and phosphate removal by chitosan immobilized Scenedesmus. Bioresour Technol 99:1274-1279. https://doi.org/10.1016/ j.biortech.2007.02.043

Filipkowska U, Jóźwiak T, Szymczyk P (2014) Application of cross-linked chitosan for phosphate removal from aqueous solutions. Prog Chem Appl Chitin Deriv 19:5-14. bwmeta1.element. psjd-4323b568-b849-4b93-9b81-83f53cde71a3

Gerchman Y, Vasker B, Tavasi M, Mishael Y, Kinel-Tahan Y, Yehoshua Y (2017) Effective harvesting of microalgae: comparison of different polymeric flocculants. Bioresour Technol 228:141-146. https://doi.org/10.1016/j.biortech.2016.12.040

Ghimici L, Brunchi CE, Diaconu A (2016) Removal of some commercial pesticides containing $\alpha$-cypermethrin, deltamethrin and mancozeb as active ingredients by chitosan solution. Cellulose 23:3837-3846

Goosen MFA (ed) (1997) Applications of chitin and chitosan. CRC Press LLC, Boca Raton, 336 p. ISBN: 9781566764490

Gregory J, Barany S (2011) Adsorption and flocculation by polymers and polymer mixtures. Adv Colloid Interf Sci 169:1-12. https://doi.org/10.1016/j.cis.2011.06.004

Guibal E, Roussy J (2007) Coagulation and flocculation of dye-containing solutions using a biopolymer (chitosan). React Funct Polym 67:33-42. https://doi.org/10.1016/j. reactfunctpolym.2006.08.008

Gupta SK, Kumar NM, Guldhe A, Ansari FA, Rawat I, Nasr M, Bux F (2018) Wastewater to biofuels: comprehensive evaluation of various flocculants on biochemical composition and yield of microalgae. Ecol Eng 117:62-68. https://doi.org/10.1016/j.ecoleng.2018.04.005

Hargreaves AJ, Vale P, Whelan J, Alibardi L, Constantino C, Dotro G, Cartmell E, Campo P (2018) Coagulation-flocculation process with metal salts, synthetic polymers and biopolymers for the removal of trace metals (cu, $\mathrm{Pb}, \mathrm{Ni}, \mathrm{Zn}$ ) from municipal wastewater. Clean Techn Environ Policy 20:393-402. https://doi.org/10.1007/s10098-017-1481-3

Jia SY, Yang Z, Ren KX, Tian ZQ, Dong C, Ma RX, Yu G, Yang WB (2016) Removal of antibiotics from water in the coexistence of suspended particles and natural organic matters using amino-acid-modified-chitosan flocculants: a combined experimental and theoretical study. J Hazard Mater 317:593-601. https://doi.org/10.1016/j.jhazmat.2016.06.024

Jin Y, Pei HY, Hu WR, Zhu YW, Xu HZ, Ma CX, Sun JM, Li HM (2017) A promising application of chitosan quaternary ammonium salt on Microcystis aeruginosa cells removal in drinking water. Sci Total Environ 583:496-504

Kadokawa JI (2018) Enzymatic preparation of functional polysaccharide hydrogels by phosphorylase catalysis. Pure Appl Chem 90:1045-1054. https://doi.org/10.1515/pac-2017-0802

Kanmani P, Aravind J, Kamaraj M, Sureshbabu P, Karthikeyan S (2017) Environmental applications of chitosan and cellulosic biopolymers: a comprehensive outlook. Bioresour Technol 242:295-303. https://doi.org/10.1016/j.biortech.2017.03.119

Kjeldsen P, Barlaz MA, Rooker AP, Baun A, Ledin A, Christensen T (2002) Present and long-term composition of MSW landfill leachate: a review. Environ Sci Technol 32:297-336. https://doi. org/10.1080/10643380290813462

Kurita K (1998) Chemistry and application of chitin and chitosan. Polym Degrad Stab 59:117-120. https://doi.org/10.1016/S0141-3910(97)00160-2

Kurita K (2006) Chitin and chitosan: functional biopolymers from marine crustaceans. Mar Biotechnol 8:203-226. https://doi.org/10.1007/s10126-005-0097-5

Kyzas GZ, Bikiaris DN, Mitropoulos AC (2017) Chitosan adsorbents for dye removal: a review. Polym Int 66:1800-1811. https://doi.org/10.1002/pi.5467 
Laamanen CA, Ross GM, Scott JA (2016) Flotation harvesting of microalgae. Renew Sust Energ Rev 58:75-86. https://doi.org/10.1016/j.rser.2015.12.293

Lama S, Muylaert K, Karki TB, Foubert I, Henderson RK, Vandamme D (2016) Flocculation properties of several microalgae and a cyanobacterium species during ferric chloride, chitosan and alkaline flocculation. Bioresour Technol 220:464-470. https://doi.org/10.1016/j.biortech. 2016.08.080

Lamia C, Abdelghani CF (2017) The removal of suspended matter by natural coagulants for low brackish water. Desalin Water Treat 79:142-151. https://doi.org/10.5004/dwt.2017.20785

Latifian M, Liu J, Mattiasson B (2014) Recovery of struvite via coagulation and flocculation using natural compounds. Environ Technol 35:2289-2295. https://doi.org/10.1080/09593330.2014. 902110

Lee CH, Liu JC (2000) Enhanced sludge dewatering by dual polyelectrolytes conditioning. Water Res 34:4430-4436. https://doi.org/10.1016/S0043-1354(00)00209-8

Lee KE, Morad N, Teng TT, Poh BT (2012) Development, characterization and the application of hybrid materials in coagulation/flocculation of wastewater: a review. Chem Eng J 203:370-386. https://doi.org/10.1016/j.cej.2012.06.109

Lee CS, Robinson J, Chong MF (2014) A review on application of flocculants in wastewater treatment. Process Saf Environ Prot 92:489-508. https://doi.org/10.1016/j.psep.2014.04.010

Levine NM (1981) Natural polymer sources. In: Schwoyer WLK (ed) Polyelectrolytes for water and wastewater treatment. CRC Press, Boca Raton, pp 47-60. ISBN: 9780849354397

Li CB, Hein S, Wang K (2008) Biosorption of chitin and chitosan. Mater Sci Technol 24:1088-1099. https://doi.org/10.1179/17438408X341771

Liu C, Bai R (2014) Recent advances in chitosan and its derivatives as adsorbents for removal of pollutants from water and wastewater. Curr Opin Chem Eng 4:62-70. https://doi.org/10.1016/j. coche.2014.01.004

Liu BZ, Chen X, Zheng HL, Wang YL, Sun YJ, Zhao CL, Zhang SX (2018) Rapid and efficient removal of heavy metal and cationic dye by carboxylate-rich magnetic chitosan flocculants: role of ionic groups. Carbohydr Polym 181:327-336. https://doi.org/10.1016/j.carbpol.2017.10.089

Lou T, Cui GP, Xun JJ, Wang XJ, Feng NY, Zhang J (2018) Synthesis of a terpolymer based on chitosan and lignin as an effective flocculant for dye removal. Colloids Surf A Physicochem Eng Asp 537:149-154. https://doi.org/10.1016/j.colsurfa.2017.10.012

Lu X, Xu Y, Sun W, Sun Y, Zheng H (2017) UV-initiated synthesis of a novel chitosan-based flocculant with high flocculation efficiency for algal removal. Sci Total Environ 609:410-418. https://doi.org/10.1016/j.scitotenv.2017.07.192

Lürling M, Noyma NP, de Magalhães L, Miranda M, Mucci M, van Oosterhout F, Huszar VLM, Marinho MM (2017) Critical assessment of chitosan as coagulant to remove cyanobacteria. Harmful Algae 66:1-12. https://doi.org/10.1016/j.hal.2017.04.011

Ma CX, Pei HY, Hu WR, Cheng J, Xu HZ, Jin Y (2016a) Significantly enhanced dewatering performance of drinking water sludge from a coagulation process using a novel chitosanaluminum chloride composite coagulant in the treatment of cyanobacteria-laden source water. RSC Adv 6:61047-61056. https://doi.org/10.1039/c6ra11989a

Ma CX, Hu WR, Pei HY, Xu HZ, Pei RT (2016b) Enhancing integrated removal of Microcystis aeruginosa and adsorption of microcystins using chitosan-aluminum chloride combined coagulants: effect of chemical dosing orders and coagulation mechanisms. Colloid Surf A 490:258-267

Martinez-Quiroz M, Lopez-Maldonado EA, Ochoa-Teran A, Pina-Luis GE, Oropeza-Guzman MT (2018) Modification of chitosan with carbamoyl benzoic acids for testing its coagulantflocculant and binding capacities in removal of metallic ions typically contained in plating wastewater. Chem Eng J 332:749-756. https://doi.org/10.1016/j.cej.2017.09.042

Meera GT, Emilia A (2006) Polyionic hydrocolloids for the intestinal delivery of protein drugs: alginate and chitosan - a review. J Control Release 114:1-14. https://doi.org/10.1016/j.jconrel. 2006.04.017 
Mohamed MH, Ajaero C, McMartin DW, Peru KM, Friesen V, Simair M, Headley JV, Wilson LD (2018) Solubilized chitosan biopolymers for analysis of organic acids in aquatic environments after phytodegradation. IJ Tech, submitted. MS ID \#CE-2301

Momemi MM, Kahforoushan D, Abbasi F, Ghanbarian S (2018) Using chitosan/CHPATC as coagulant to remove colr and turbidity of industrial wastewater: optimization through RSM design. J Environ Manag 211:347-355. https://doi.org/10.1016/j.jenvman.2018.01.031

Morin-Crini N, Crini G (eds) (2017) Eaux industrielles contaminées. PUFC Press, Besançon, 513 p. ISBN: 978-2-84867-589-3

MPOB (2012) Overview of the Malaysian oil palm industry 2011. Shah Alam Econ Ind Dev Div. http://palmoilis.mpob.gov.my/index.php/overview-of-industry/224-overview-of-industry-2011

Mucci M, Noyma NP, de Magalhaes L, Miranda M, van Oosterhout F, Guedes IA, Huszar VLM, Marinho MM, Lurling M (2017) Chitosan as coagulant on cyanobacteria in lake restoration management may cause rapid cell lysis. Water Res 118:121-130. https://doi.org/10.1016/j. watres.2017.04.020

Muzzarelli RAA (1973) Natural chelating polymers. Pergamon Press, Oxford. ISBN-10: 008017235

Muzzarelli RAA (1988) Carboxymethylated chitins and chitosans. Carbohydr Polym 8:1-21. https://doi.org/10.1016/0144-8617(88)90032-X

Nascimento IOC, Guedes ARP, Perelo LW, Queiroz LM (2016) Post-treatment of sanitary landfill leachate by coagulation-flocculation using chitosan as primary coagulant. Water Sci Technol 74:246-255. https://doi.org/10.2166/wst.2016.203

Nechita P (2017) Chapter 10: Applications of chitosan in wastewater treatment. In: Shalaby EA (ed) Biological activities and application of marine polysaccharides. InTech, Rijeka, pp 209-228. https://doi.org/10.5772/65289

Newcombe G (ed) (2009) International guidance manual for the management of toxic cyanobacteria. Global Water Research Coalition and Water Quality Research Australia, London

No HK, Meyers SP (1995) Preparation and characterization of chitin and chitosan - a review. J Aquat Food Prod Technol 4:27-52. https://doi.org/10.1300/J030v04n02_03

No HK, Meyers SP (2000) Application of chitosan for treatment of wastewaters. Rev Environ Contam Toxicol 63:1-28. https://doi.org/10.1007/978-1-4757-6429-1_1

Nwe N, Furuike T, Tamura H (2011) Chapter 2: Chitosan from aquatic and terrestrial organisms and microorganisms. Production, properties and applications. In: Johnson BM, Berkel ZE (eds) Biodegradable materials. Nova Science Publishers, Inc, New York, pp 29-50

Oladoja NA (2015) Headway on natural polymeric coagulants in water and wastewater treatment operations. J Water Process Eng 6:174-192. https://doi.org/10.1016/j.jwpe.2015.04.004

Onsoyen E, Skaugrud O (1990) Metal recovery using chitosan. J Chem Technol Biotechnol 49:395-404

Pakdel PR, Peighambardoust SJ (2018) Review on recent progress in chitosan-based hydrogels for wastewater treatment application. Carbohydr Polym 201:264-279. https://doi.org/10.1016/j. carbpol.2018.08.070

Pambi RLL, Musonge P (2015) The efficiency of chitosan as a coagulant in the treatment of the effluents from the sugar industry. J Polym Mater 32:57-63

Pan G, Zou H, Chen H, Yuan X (2006) Removal of harmful cyanobacterial blooms in Taihu Lake using local soils. III. Factors affecting the removal efficiency and an in situ field experiment using chitosan-modified local soils. Environ Pollut 141:206-212

Parthasarathy S, Gomes RL, Manickam S (2016) Process intensification of anaerobically digested palm oil mill effluent (AAD-POME) treatment using combined chitosan coagulation, hydrogen peroxide $\left(\mathrm{H}_{2} \mathrm{O}_{2}\right)$ and Fenton's oxidation. Clean Techn Environ Policy 18:219-230. https://doi. org/10.1007/s10098-015-1009-7

Pei HY, Ma CX, Hu WR, Sun F (2014) The behaviors of Microcystis aeruginosa cells and extracellular microcystins during chitosan flocculation and flocs storage processes. Bioresour Technol 151:314-322 
Pei HY, Xu HZ, Xiao HD, Sun JM, Hu WR, Li XQ, Ma CX, Jin Y (2016) Using a novel hydrogenterminated porous $\mathrm{Si}$ wafer to enhance Microcystis aeruginosa effective removal by chitosan at a low dosage. Colloid Surf A 499:88-96

Pérez-Calderón J, Santos MV, Zaritzky N (2018) Optimal clarification of emulsified oily wastewater using a surfactant/chitosan biopolymer. J Environ Chem Eng 6:3808-3818. https://doi.org/ 10.1016/j.jece.2018.06.004

Peters MG (1995) Applications and environmental aspects of chitin and chitosan. J Mat Sci Pure Appl Chem A32:629-640. https://doi.org/10.1080/10601329508010276

Prado HJ, Matulewicz MC (2014) Cationization of polysaccharides: a path to greener derivatives with many industrial applications. Eur Polym J 52:53-75. https://doi.org/10.1016/j.eurpolymj. 2013.12.011

Qi Y, Thapa KB, Hoadley AFA (2011) Benefit of lignite as a filter aid for dewatering of digested sewage sludge demonstrated in pilot scale trials. Chem Eng J 166:504-510. https://doi.org/10. 1016/j.cej.2010.11.003

Quinlan PJ, Tanvir A, Tam KC (2015) Application of the central composite design to study the flocculation of an anionic azo dye using quaternized cellulose nanofibrils. Carbohydr Polym 133:80-89. https://doi.org/10.1016/j.carbpol.2015.06.095

Rahmanifar B, Moradi-Dehaghi S (2014) Removal of organochlorine pesticides by chitosan loaded with silver oxide nanoparticles from water. Clean Techn Environ Policy 16:1781-1786. https:// doi.org/10.1007/s10098-013-0692-5

Ramirez L, Gentile SR, Zimmermann S, Stoll S (2016) Comparative study of the effect of aluminum chloride, sodium alginate and chitosan on the coagulation of polystyrene microplastic particles. J Colloid Sci Biotechnol 5:190-198. https://doi.org/10.1166/jcsb.2016.1149

Ramli SF, Aziz HA (2015) Use of ferric chloride and chitosan as coagulant to remove turbidity and color from landfill leachate. Appl Mech Mater 773:1163-1167. https://doi.org/10.4028/www. scientific.net/AMM.773-774.1163

Rani M, Shanker U, Jassal V (2017) Recent strategies for removal and degradation of persistent \& toxic organochlorine pesticides using nanoparticles: a review. J Environ Manag 190:208-222. https://doi.org/10.1016/j.jenvman.2016.12.068

Rashid S, Shen C, Yang J, Liu J, Li J (2018) Preparation and properties of chitosan-metal complex: some factors influencing the adsorption capacity for dyes in aqueous solution. J Environ Sci 66:301-309. https://doi.org/10.1016/j.jes.2017.04.033

Ravi Kumar MNV (2000) A review of chitin and chitosan applications. React Funct Polym 46:1-27. https://doi.org/10.1016/S1381-5148(00)00038-9

Renault F, Badot PM, Crini G (2009a) Chitosan for flocculation processes - an eco-friendly approach. In: Rustichelli F, Caramella ŞS, Vårum KM (eds) Advances in chitin science, vol XI, pp 360-366

Renault F, Sancey B, Badot PM, Crini G (2009b) Use of chitosan as a bioflocculant to treat biological wastewater from pulp and paper plant. In: Rustichelli F, Caramella, Şenel S, Vårum KM (eds) Advances in chitin science. Volume XI, pp 407-412

Renault F, Sancey B, Charles J, Morin-Crini N, Badot PM, Winterton P, Crini G (2009c) Chitosan flocculation of cardboard-mill secondary biological wastewater. Chem Eng J 155:775-783. https://doi.org/10.1016/cej.2009.09.023

Renault F, Sancey B, Badot PM, Crini G (2009d) Chitosan for coagulation/flocculation processes an eco-friendly approach. Eur Polym J 45:1337-1348. https://doi.org/10.1016/j.eurpolymj. 2008.12.027

Renou S, Givaudan JG, Poulain S, Dirassouyan F, Moulin P (2008) Landfill leachate treatment: review and opportunity. J Hazard Mater 150:468-493. https://doi.org/10.1016/j.jhazmat.2007. 09.077

Rinaudo M (2006) Chitin and chitosan: properties and applications. Prog Polym Sci 31:603-632. https://doi.org/10.1016/j.progpolymsci.2006.06.001

Ripperger S, Gösele W, Alt C (2012) Filtration, 1. Fundamentals, vol 14. Wiley-VCH GmbH \& Co. KGaA, Weinheim, pp 677-709. https://doi.org/10.1002/14356007.b02_10.pub2 
Roberts GAF (1992) Chitin chemistry, 1st edn. Macmillan Press, Houndmills, London. ISBN: 9780333524176

Ruelas-Leyva JP, Contreras-Andrade I, Sarmiento-Sanchez JI, Licea-Claverie A, Jimenez-Lam SA, Cristerna-Madrigal YG, Picos-Corrales LA (2017) The effectiveness of Moringa oleifera seed flour and chitosan as coagulant-flocculants for water treatment. Clean Soil Air Water 45:1600339. https://doi.org/10.1002/clen.201600339

Rushdy R, Reza M, McKay G (2014) Combined magnetic field and adsorption process for treatment of biologically treated palm oil mill effluent (POME). Chem Eng J 243:31-42. https://doi.org/10.1016/j.cej.2013.12.084

Saeed MO, Azizli KAM, Isa MH, Ezechi EH (2016) Treatment of POME using Fenton oxidation process: removal efficiency, optimization, and acidity condition. Desalin Water Treat 57:23750-23759. https://doi.org/10.1080/19443994.2016.1141715

Sajjad A, Rizwan M, Mujtaba G, Rashid N (2017) Chitosan as a flocculant: an approach to improve its solubility for efficient harvesting of microalgae. Korean Chem Eng Res 55:530-534. https:// doi.org/10.9713/kcer.2017.55.4.530

Salehizadeh H, Yan N, Farnood R (2018) Recent advances in polysaccharides bio-based flocculants. Biotechnol Adv 36:92-119. https://doi.org/10.1016/j.biotechadv.2017.10.002

Sami AJ, Khalid M, Iqbal S, Afzal M, Shakoori AR (2017) Synthesis and application of chitosanstarch based nanocomposite in wastewater treatment for the removal of anionic commercial dyes. Pak J Zool 49:21-26

Schindler DW, Hecky RE, McCullough GK (2012) The rapid eutrophication of Lake Winnipeg: greening under global change. J Great Lakes Res 38:6-13

Shankar A, Kongot M, Saini VK, Kumar A (2018) Removal of pentachlorophenol pesticide from aqueous solutions using modified chitosan. Arabian J Chem (in press). https://doi.org/10.1016/j. arabjc.2018.01.016

Shi YL, Ma J, Yang JX (2017) Improved dissolved air flotation performances using chitosan under different dosing schemes. Pol J Environ Stud 26:2731-2737. https://doi.org/10.15244/pjoes/ 73806

Sila A, Mlaik N, Sayari N, Balti R, Bougatef A (2014) Chitin and chitosan extracted from shrimp waste using fish proteases aided process: efficiency of chitosan in the treatment of unhairing effluents. J Polym Environ 22:78-87. https://doi.org/10.1007/s10924-013-0598-7

Skjåk-Braek G, Anthonsen T, Sandford PA (eds) (1989) Chitin and chitosan. Sources, chemistry, biochemistry, physical properties and applications. Elsevier Applied Science, New York, 835 p. ISBN: 978-1-85166-395-8

Song Z, Li G, Guan F, Liu W (2018) Application of chitin/chitosan and their derivatives in the papermaking industry. Polymers 10:1-14. https://doi.org/10.3390/polym10040389

Stechemesser H, Dobiáš B (eds) (2005) Coagulation and flocculation, Surfactant Science Series, vol 126, 2nd edn. CRC Press/Taylor \& Francis, Boca Raton, 861 p. ISBN: 9781574444551

Steed JW, Atwood JL (2009) Supramolecular chemistry, 2nd edn. Wiley, West Sussex. ISBN: 9781118681503

Sudha PN (2011) Chapter 39: Chitin/chitosan and derivatives for wastewater treatment. In: Kim SK (ed) Chitin, chitosan, oligosaccharides and their derivatives: biological activities and applications. CRC Press/Taylor \& Francis Group, LLC, Boca Raton, pp 561-588. ISBN: 9781439816035

Sudha PN, Aisverya S, Gomathi T, Vijayalakshmi K, Saranya M, Sangeetha K, Latha S, Thomas S (2017) Chapter 17: Applications of chitin/chitosan and its derivatives as adsorbents, coagulants and flocculants. In: Ahmed S, Ikram S (eds) Chitosan - derivatives, composites and applications. Scrivener Publishing LLC/Wiley, Beverly/Hoboken, pp 453-487. https://doi.org/10. 1002/9781119364849.ch17

Suopajärvi T, Liimatainen H, Hormi O, Niinimäki J (2003) Coagulation-flocculation treatment of municipal wastewater based on anionized nanocelluloses. Chem Eng J 231:59-67. https://doi. org/10.1016/j.cej.2013.07.010 
Tadza MYM, Sobani HHM, Ghani NAF (2015) Characteristics of struvite precipitate from palm oil mill effluent. J Sci Technol Trop 11:1-9

Tadza MYM, Ghani NAF, Sobani HHM (2016) Evaluation of sludge from coagulation of palm oil mill effluent with chitosan based coagulant. Jurnal Teknologi 78:19-22. https://doi.org/10. 11113/jt.v78.8529

Teng D (2016) Chapter 1: From chitin to chitosan. In: Yao K, Li J, Yao F, Yin Y (eds) Chitosanbased hydrogels: functions and applications. CRC Press/Taylor \& Francis Group, Boca Raton, pp 1-38. ISBN: 9781138076846

Torres K, Álvarez-Hornos FJ, San-Valero P, Gabaldón C, Marzal P (2018) Granulation and microbial community dynamics in the chitosan-supplemented anaerobic treatment of wastewater polluted with organic solvents. Water Res 130:376-387. https://doi.org/10.1016/j.watres. 2017.12.009

Ujang Z, Diah M, Rashid AHA, Halim AS (2011) Chapter 6: The development, characterization and application of water soluble chitosan. In: Elnashar M (ed) Biotechnology of biopolymers. InTech, Rijeka, pp 109-130. https://doi.org/10.5772/16771

Ummalyma SB, Gnansounou E, Sukumaran RK, Sindhu R, Pandey A, Sahoo D (2017) Bioflocculation: an alternative strategy for harvesting of microalgae - an overview. Bioresour Technol 242:227-235. https://doi.org/10.1016/j.biortech.2017.02.097

Vakili M, Rafatullah M, Salamatinia B, Abdullah AZ, Ibrahim MH, Tan KB, Gholami Z, Amouzgar P (2014) Application of chitosan and its derivatives as adsorbents for dye removal from water and wastewater: a review. Carbohydr Polym 113:115-130. https://doi.org/10.1016/j. carbpol.2014.07.007

Van Tran V, Park D, Lee YC (2018) Hydrogel applications for adsorption of contaminants in water and wastewater treatment. Environ Sci Pollut Res 25:24569-24599. https://doi.org/10.1007/ s11356-018-2605-y

Vandenbossche M, Jimenez M, Casetta M, Traisnel M (2015) Remediation of heavy metals by biomolecules: a review. Crit Rev Environ Sci Technol 45:1644-1704. https://doi.org/10.1080/ 10643389.2014.966425

Vårum KM, Smidsrød O (2004) Chapter 26: Structure-property relationship in chitosan. In: Dumitriu S (ed) Polysaccharides: structural diversity and functional versatility. Marcel Dekker, New York, pp 625-641. ISBN: 9780824754808

Verma AK, Dash RR, Bhunia P (2012) A review on chemical/flocculation technologies for removal of colour from textile wastewaters. J Environ Manag 93:154-168. https://doi.org/10.1016/j. jenvman.2011.09.01

Wang J, Zhuang S (2017) Removal of various pollutants from water and wastewater by modified chitosan adsorbents. Crit Rev Environ Sci Technol 47:2331-2386. https://doi.org/10.1080/ 10643389.2017.1421845

Wang WY, Yue QY, Li RH, Song W, Gao BY, Shen X (2017) Investigating coagulation behavior of chitosan with different Al species dual-coagulants in dye wastewater treatment. J Taiwan Inst Chem Eng 78:423-430. https://doi.org/10.1016/j.jtice.2017.06.052

Wei H, gao B, Ren J, Li A, Yang H (2018) Coagulation/flocculation in dewatering of sludge: a review. Water Res 143:608-631. https://doi.org/10.1016/j.watres.2018.07.029

Wilson LD, Tewari BB (2018) Chitosan-based adsorbents: environmental applications for the removal of arsenicals. Mater Res Found 34:133-160. https://doi.org/10.21741/ 9781945291753-7

Wilson LD, Pratt DY, Kozinski JA (2013) Preparation and sorption studies of $\beta$-cyclodextrinchitosan-glutaraldehyde terpolymers. J Colloid Interface Sci 393:271-277. https://doi.org/10. 1016/j.jcis.2012.10.046

Wu TY, Mohammad AW, Jahim JM, Anuar N (2010) Pollution control technologies for the treatment of palm oil mill effluent (POME) through end-of-pipe processes. J Environ Manag 91:1467-1490. https://doi.org/10.1016/j.jenvman.2010.02.008 
Xie Q, Lin T, Chen F, Wang D, Yang B (2018) Recovery of ultra-trace palladium using chitosan and its sulphur-containing derivative in $\mathrm{HCl}$ medium. Hydrometallurgy 178:188-194. https:// doi.org/10.1016/j.hydromet.2018.04.007

Xu HZ, Pei HY, Xiao HD, Jin Y, Li XQ, Hu WR, Ma CX, Sun JM, Li HM (2016) Behaviors of Microcystis aeruginosa cells during floc storage in drinking water treatment process. Sci Rep 6:34943. https://doi.org/10.1038/srep34943

Yang K, Li Z, Zhang H, Qian J, Chen G (2010) Municipal wastewater phosphorus removal by coagulation. Environ Technol 31:601-609. https://doi.org/10.1080/09593330903573223

Yang R, Li H, Huang M, Yang H, Li A (2016) A review on chitosan-based flocculants and their applications in water treatment. Water Res 95:59-89. https://doi.org/10.1016/j.watres.2016.02. 068

Yong SK, Shrivastava M, Srivastava P, Kunhikrishnan A, Bolan N (2015) In: Whitacre DM (ed) Environmental applications of chitosan and its derivatives, Book Series: Reviews of Environmental Contamination and Toxicology, vol 233. Springer, Cham, pp 1-43. https://doi. org/10.1007/978-3-319-10479-9_1

You LJ, Song LD, Lu FF, Zhang QQ (2016) Fabrication of a copolymer flocculant and application for Cr(VI) removal. Polym Eng Sci 56:1213-1220. https://doi.org/10.1002/pen.24354

Yu GH, He PJ, Shao LM, He PP (2008) Stratification structure of sludge flocs with implications to dewaterability. Environ Sci Technol 42:7944-7949. https://doi.org/10.1021/es8016717

Yunos FHM, Nasir NM, Jusoh HHW, Khatoon H, Lam SS, Jusoh A (2017) Harvesting of microalgae (Chlorella sp.) from aquaculture bioflocs using an environmental-friendly chitosan-based bio-coagulant. Int Biodeterior Biodegrad 124:243-249. https://doi.org/10. 1016/j.ibiod.2017.07.016

Zahrim AY, Tizaoui C, Hilal N (2011) Coagulation with polymers for nanofiltration pre-treatment of highly concentrated dyes: a review. Desalination 266:1-16. https://doi.org/10.1016/j.desal. 2010.08.012

Zemmouri H, Mameri N, Lounici H (2015) Chitosan use in chemical conditioning for dewatering municipal-activated sludge. Water Sci Technol 71:810-816. https://doi.org/10.2166/wst.2014. 532

Zhai LF, Sun M, Song W, Wang G (2012) An integrated approach to optimize the conditioning chemicals for enhanced sludge conditioning in a pilot-scale sludge dewatering process. Bioresour Technol 121:161-168. https://doi.org/10.1016/j.biortech.2012.06.093

Zhang CL, Zhang MY, Chang Q (2015) Preparation of mercaptoacetyl chitosan and its removal performance of copper ion and turbidity. Des Water Treat 53:1909-1916. https://doi.org/10. 1080/19443994.2013.870743

Ziyang L, Youcai Z, Tao Y, Yu S, Huili C, Nanwen Z, Renhua H (2009) Natural attenuation and characterization of contaminants composition in landfill leachate under different disposing ages. Sci Total Environ 407:3385-3391. https://doi.org/10.1016/j.scitotenv.2009.01.028 